\title{
Plants as Sources of Anti-Inflammatory Agents
}

\author{
Clara dos Reis Nunes ${ }^{1} \oplus$, Mariana Barreto Arantes ${ }^{1}$, Silvia Menezes de Faria Pereira ${ }^{1}$, \\ Larissa Leandro da Cruz ${ }^{1}$, Michel de Souza Passos ${ }^{2}$, Luana Pereira de Moraes ${ }^{1}$, \\ Ivo José Curcino Vieira ${ }^{2}$ and Daniela Barros de Oliveira ${ }^{1, *}$ \\ 1 Laboratório de Tecnologia de Alimentos, Centro de Ciências e Tecnologias Agropecuárias, \\ Universidade Estadual do Norte Fluminense Darcy Ribeiro, Campos dos Goytacazes, RJ 28013-602, Brazil; \\ clara_biol@yahoo.com.br (C.d.R.N.); mariana.arant@yahoo.com.br (M.B.A.); silvia@uenf.br (S.M.d.F.P.); \\ larissa.leandrocruz@gmail.com (L.L.d.C.); luana@uenf.br (L.P.d.M.) \\ 2 Laboratório de Ciências Químicas, Centro de Ciências e Tecnologia, UniversidadeEstadual do Norte \\ Fluminense Darcy Ribeiro, Campos dos Goytacazes, RJ 28013-602, Brazil; \\ michelpassos19@gmail.com (M.d.S.P.); curcino@uenf.br (I.J.C.V.) \\ * Correspondence: dbarrosoliveira@uenf.br; Tel.: +55-22-988395160
}

Academic Editors: Thea Magrone, Rodrigo Valenzuela and Karel Šmejkal Received: 29 June 2020; Accepted: 5 August 2020; Published: 15 August 2020

\begin{abstract}
Plants represent the main source of molecules for the development of new drugs, which intensifies the interest of transnational industries in searching for substances obtained from plant sources, especially since the vast majority of species have not yet been studied chemically or biologically, particularly concerning anti-inflammatory action. Anti-inflammatory drugs can interfere in the pathophysiological process of inflammation, to minimize tissue damage and provide greater comfort to the patient. Therefore, it is important to note that due to the existence of a large number of species available for research, the successful development of new naturally occurring anti-inflammatory drugs depends mainly on a multidisciplinary effort to find new molecules. Although many review articles have been published in this regard, the majority presented the subject from a limited regional perspective. Thus, the current article presents highlights from the published literature on plants as sources of anti-inflammatory agents.
\end{abstract}

Keywords: drugs; inflammation; bioactive compounds

\section{Introduction}

The magnitude of global plant diversity is estimated at more than 500,000 species [1,2], and the variety and complexity of plant metabolites represent a challenge when considering exploration of the chemical repertoire offered. From this point of view, the Plant Kingdom has been pragmatic, especially when these molecules are reported as substances with the high medicinal potential to treat diseases that affect living beings [3].

Medicinal plants continue to be an interesting source of natural products for treating various health conditions. It is estimated that more than 150,000 plant species have been studied, many of which contain valuable therapeutic agents, and the applications of novel compounds from plants for pharmaceutical purposes have been gradually increasing in recent years $[4,5]$.

Plants have played an important role in human health care since ancient times. In an adaptation against attacking pathogen and environmental stress, plants produce several substances that exert biological activities. These small organic molecules come from secondary metabolism and have several biological activities. Among the diverse functions, anti-inflammatory actions are highlighted [6,7].

It is known that inflammation is an evolutionarily conserved process of protection and a critical survival mechanism [8]. It is composed of complex sequential changes in the tissue to eliminate the 
initial cause of the cell injury, which may have been caused by infectious agents or substances from their metabolism (microorganisms and toxins), as well as by physical agents (radiation, burn, and trauma), or chemicals (caustic substances) $[9,10]$. The signs of inflammation are local redness, swelling, pain, heat, and loss of function [7].

In general, this complex biological response leads to the restoration of homeostasis. However, in cases of prolonged release of inflammatory mediators and the activation of harmful signal-transduction pathways, the inflammatory process persists, and a mild but chronic proinflammatory state may arise [8]. A low-grade inflammatory state is correlated with various disorders and chronic health conditions, such as obesity, diabetes, cancer, and cardiovascular diseases, among others [11-18].

Therefore, the discovery of a new generation of therapeutic agents to use in the resolution of inflammation is desirable. The treatment of inflammation involves some mechanisms that can be used as therapeutic targets [8]. Due to the production of secondary metabolites with clinically curative effects, medicinal plants play an important role in the development of new and potent drugs [19,20].

Another motivating scientific investigation related to drugs and medicines made from plants is their interaction with gut microbiota. Certain gut bacteria intensively metabolize drugs rich in the low-molecular-mass products of secondary metabolisms, such as tannins and anthocyanins. Metabolites derived from bacterial metabolization are small, bioavailable, and potentially bioactive metabolites. They also have potential modulatory effects on the gut microbiome, which is interesting to prevent metabolic disorders [21].

\section{Anti-Inflammatory Drugs}

Anti-inflammatory drugs can interfere in the pathophysiology of inflammation, seeking to minimize tissue damage and provide greater patient comfort. The major classes of anti-inflammatory agents are the glucocorticoids and non steroidal anti-inflammatory drugs (NSAIDs). Fundamentally these differ in their mode of action. In short, glucocorticoids act by inhibiting prostaglandins and proteins involved in inflammatory processes, such as corticosteroids, which among other indications are used in treatment for asthma and autoimmune inflammatory response. Non-steroidal drugs, on the other hand, have an inhibitory action through the enzyme cyclooxygenase and are indicated for moderate and mild pain and body temperature control. An example of a non-steroidal drug is acetylsalicylic acid [22].

NSAIDs are the most commonly used drugs worldwide [7], utilized to treat acute and chronic pain resulting from an inflammatory process [22]. NSAIDs encompass a range of agents and, in general, all their effects are related to the inhibition of COX action in the production of prostaglandins and thromboxanes [23-26].

The main mechanism of action of NSAIDs is the inhibition of COX, both central and peripheral, interfering in the conversion of arachidonic acid to prostaglandins E2, prostacyclins, and thromboxanes. Enzymes related to the action of NSAIDs can be divided into COX-1 and COX-2, acting in different regions. COX-1 appears in most cells, even fetal and amniotic fluid, and participates in physiological effects, such as regulatory and protective effects. On the other hand, COX-2 is activated by inflammation and proinflammatory cytokines $[27,28]$.

There are several ways to classify NSAIDs; according to COX-2 inhibitory potency over COX-1, concentration to achieve clinical effects, among others. NSAIDs can be classified into non-selective NSAIDs (ketoprofen, aspirin, naproxen, flunixin, meglumine, and others), preferential COX-2 inhibitors (meloxican, etodolac, nimesulide), and highly selective COX-2 inhibitors (coxib). Most of the side effects are related to the inhibition of COX-1 due to its performance in several systems related to cell cleansing. Besides, NSAIDs can also be classified according to their chemical structure (Table 1). 
Table 1. Classification of NSAIDs [29].

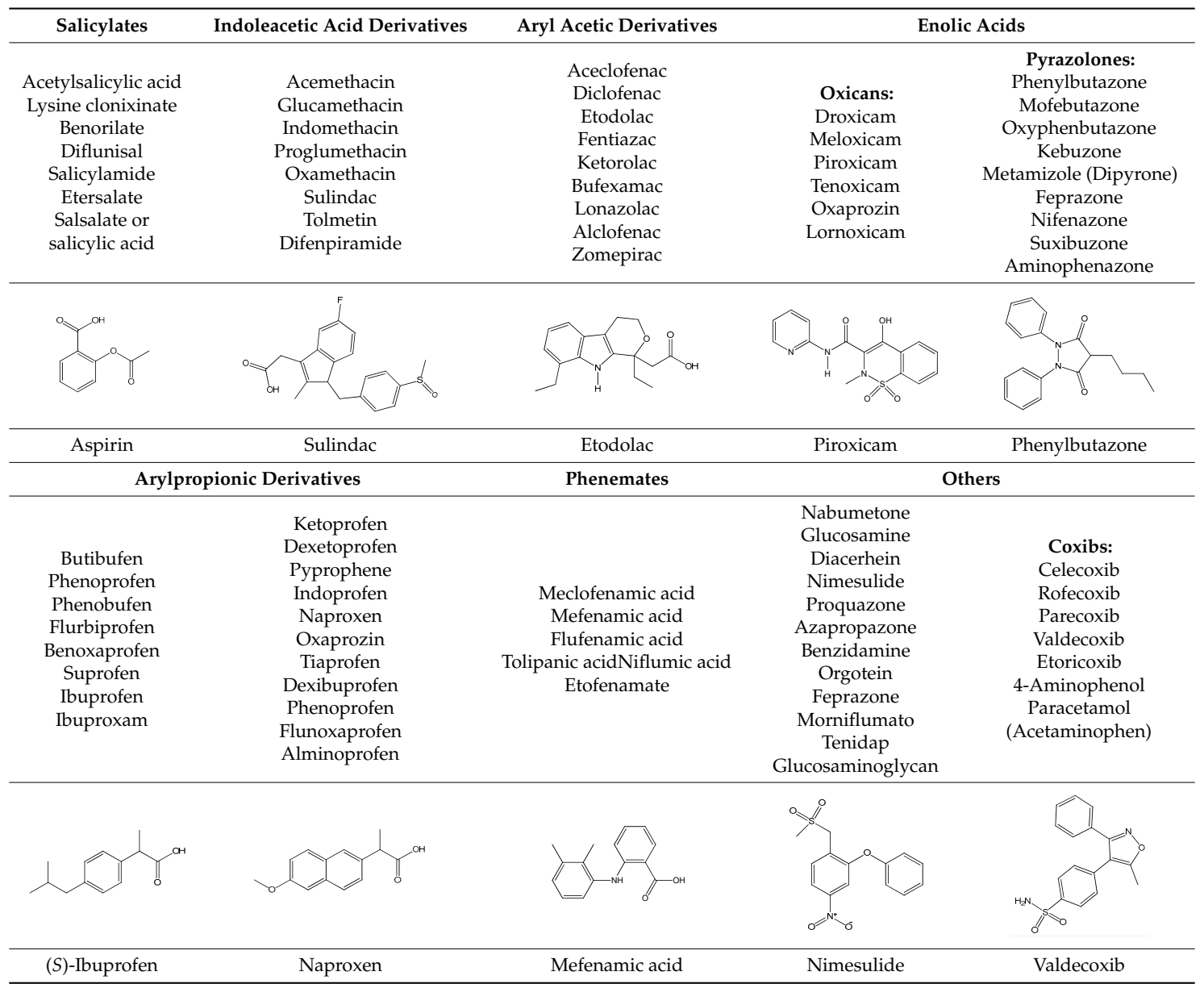

Structurally, COX-2 selective drugs contain sulfonamide groups or sulfones, responsible for the selectivity of the enzyme and do not have a carboxylic group and, therefore, they can selectively target the COX-2 enzyme. They have little water solubility, which hinders parenteral administration [30].

Acetylsalicylic acid (ASA) is one of the most widely used drugs in the world. It is used as an analgesic, antipyretic, and anti-inflammatory [31,32]. This drug also has antiplatelet or anticoagulant effects and is used to prevent heart attacks, strokes, and blood clots [33]. However, its use can also lead to exacerbated respiratory tract disease and cancer [32,34].

Historically, non-steroidal anti-inflammatory drugs, such as acetylsalicylic acid (Aspirin ${ }^{\circledR}$ ), indomethacin, ibuprofen, and piroxicam have been used clinically for the treatment of inflammation due to their suppression of the effects of COX activity [24].

However, these traditional NSAIDs act in a non-selective manner inhibiting both forms of COX and have also demonstrated side effects. Specific modalities of anti-inflammatory effects and side effects are associated with the existence of two COX isoforms [35].

Inhibitory actions of aspirin or other non-steroidal anti-inflammatory drugs against COX-1 may present crucial problems in pharmacotherapy. Some anti-inflammatory drugs that act only to inhibit COX-1 are ibuprofen, naproxen, fenoprofen, ketoprofen, flurbiprofen, and oxaprozin (derivatives of propionic acid); indomethacin, sulindac, and etodolac (indoleacetic acids); piroxicam (derived from oxyanas); mefenamic acid and meclofenamate (phanamates); and diclofenac [29].

Thus, the scientific community has focused its efforts on the search for selective COX-2 inhibitors, with lower adverse side effects, since highly selective COX-2 inhibitors are required for the treatment of inflammatory diseases [35]. The first selective COX-2 inhibitor was celecoxib (Celebrex ${ }^{\circledR}$ ), followed by rofecoxib $\left(\operatorname{Viox}{ }^{\circledR}\right)$. In a short time, the coxibs (celecoxib and rofecoxib) have achieved wide 
dissemination [36]. Other drugs are also more selective for COX-2 than for COX-1, such as nimesulide and etodolac [37].

Despite initial success, shortly after the launch of selective COX-2 inhibitors, adverse cardiovascular and renal effects have been reported and, in high-doses, gastrointestinal effects. These adverse effects occur due to inhibition of the constitutive production of COX-2 in some tissues. Thus, in recent years, the safety of the use of NSAIDs in clinical practice has been questioned, due to the emergence of evidence that suggests a high risk of acute myocardial infarction, stroke, heart failure, renal failure, and arterial hypertension [30,38].

There is no absolute selectivity in COXs. Even a selective COX-2 inhibitor will also inhibit COX-1 when in high concentrations. Therefore, in all NSAIDs selective for COX-1 or COX-2, to different degrees, there is a risk of adverse cardiovascular side effects [30].

In September 2004, Merck removed Vioxx ${ }^{\circledR}$ from the world market and in April 2005, the coxib study led the American Committee to conclude about the Cardiovascular Risk and suspension of Pfizer's Bextra ${ }^{\circledR}$ (valdecoxib). Celecoxib is marketed only with a black stripe indication and the adverse cardiovascular effects are explained in the package leaflet [36].

A derivative of celecoxib based a benzo[b]furan moiety was reported to demonstrate selective activity against COX-2. Besides, new molecules containing rhodanine and benzofuran scaffolds were designed, synthesized, and reported to exhibit dual COX-2, and 5-LOX inhibitory potential [39,40]. A recent patent survey reported a review focused on benzofuran inhibitors [41,42].

Since a large proportion of NSAIDs available on the market have significant undesirable effects, the need for new anti-inflammatory drugs contributes to the advancement of research for newer, safer, effective molecules with fewer side effects and from vegetal sources. Therefore, it can be observed that a significant number of substances of vegetal origin form part of the therapeutic arsenal of modern medicine. It is important to emphasize that due to the existence of a large number of species available for research, the success of the development of new naturally occurring anti-inflammatory drugs depends fundamentally on a multidisciplinary effort in the discovery of new leading molecules.

\section{Plant Use and the Development of Drugs}

The World Health Organization (WHO) estimates that approximately $65 \%$ of the world's population incorporates traditional medicine (ethnobotanical uses) into medical care. Ethnobotanical studies over the years have allowed the association of highly diversified plants with biological activities, from observation, description, and experimental research, which has greatly contributed to the discovery of natural products with biological action. The use of medicinal plant-based natural compounds to treat many illnesses has become a great trend in clinical research. Polyphenolic compounds have drawn significant attention due to their modulation effects on inflammasomes [43]. These multi-protein complexes are associated with the initiation and progression of metabolic disorders and chronic diseases, such as cancer and neurodegenerative diseases [44].

Thus, plants have become the first source of substances for the development of new drugs, and a considerable part of the drugs prescribed in the world are derived from them [9,45-47]. Plants contain reservoirs of potential secondary metabolites that are the major sources of drugs, which intensifies the interest of transnational industries in the search for substances obtained from plant sources, particularly since the great majority of species have not been studied chemically or biologically [48].

The use of plants or plant products for medicinal purposes is mostly documented in books and, lately, on an enormous number of websites (the reliability of some of which must be examined carefully). In recent decades, hundreds of research and review articles have been published regarding the anti-inflammatory activities of plants (Table 2) [7,49-52]. 
Table 2. Anti-inflammatory activity of some medicinal plants.

\begin{tabular}{|c|c|c|c|c|}
\hline Number & Botanical Name & Plant/Family & Parts Used & Constituent Compounds \\
\hline 01 & Acacia catechu & Mimosaceae & Bark, wood, flowering tops, gum. & Tannin, gum, catechuic acid \\
\hline 02 & Azadirachta indica & Meliaceae & Leaf, root, oil, seed, gum, fruit, flower. & Margosine, bitter oil, azadirachtin. \\
\hline 03 & Caesalpinia crista & Caesalpiniaceae & Seeds, root, leaf, root bark. & $\begin{array}{c}\text { Oleic, linoleic, palmitic, stearic acid, } \\
\text { phytosterols. }\end{array}$ \\
\hline 04 & Cassia angustifolia & Caeasalpinaceae & Pods, dried leaves. & $\begin{array}{l}\text { Emodin, eatharitin, mucilage, senna-picrin, } \\
\text { opleanic acid. }\end{array}$ \\
\hline 05 & Coriandrum sativum & Umbelliferaeapiaceae & Leaf, bark, flower & $\begin{array}{l}\text { Tannin, cathartin, malic acid, } \\
\text { cathartin, albuminoids. }\end{array}$ \\
\hline 06 & Cuscuta reflexa & Convolvulaceae & Plant, seed, fruit, stem. & $\begin{array}{l}\text { Cuscutine, flavonoid, glucoside, } \\
\text { bergenin, coumarin. }\end{array}$ \\
\hline 07 & Enicostema littorale & Gentianaceae & Whole plant. & Alkaloids, gentiocrucine \\
\hline 08 & Erythrina variegate & Papilionaceae & Leaves, bark, roots, flower. & 2-Hydroxygenistein, genistein. \\
\hline 09 & Euphorbia hirta & Euphorbiaceae & Plant, roots, leaves & $\begin{array}{l}\text { Ascorbic acid, } \beta \text {-amyrin, choline, inositol, } \\
\text { linoleic acid, } \beta \text {-sitosterol. }\end{array}$ \\
\hline 10 & Euphorbia tirucalli & Euphorbiaceae & Root, plant (milk, juice). & $\begin{array}{l}\beta \text {-sitosterol, ellagic acid, citric acid, } \\
\text { malic acid, eupholglucose. }\end{array}$ \\
\hline 11 & Fagonia cretica & Zygophyllaceae & Leaves, twigs, bark. & Betulin \\
\hline 12 & Ficus benghalensis & Moraceae & $\begin{array}{l}\text { Aerial roots, bark, seeds, leaves, buds, } \\
\text { fruits, latex. }\end{array}$ & Skin, fruits contain $10 \%$ tannin. \\
\hline 13 & Ficus carica & Moraceae & Fruit, root. & $\begin{array}{c}\text { Alkaloids, ascorbic acid, caffeic acid, niacin, } \\
\text { linoleic acid, lutein, } \beta \text {-carotene, } \\
\text { pantothenic acid, } \beta \text {-amyrin. }\end{array}$ \\
\hline 14 & Ficus religiosa & Moraceae & $\begin{array}{l}\text { Bark, leaves, fruits, } \\
\text { tender shoots, seeds. }\end{array}$ & The bark contains tannins, rubber, wax. \\
\hline 15 & Foeniculum vulgare & Apiaceae & Fruit, root, seeds, leaves. & $\begin{array}{c}\text { Ascorbic acid, estragole, coumaric acid, } \\
\text { caffeic acid, } \alpha \text {-terpinene, scoparone, } \\
\text { scopoletin, cynarin, D-limonene, } \\
\alpha \text {-phellandrene. }\end{array}$ \\
\hline 16 & Gentiana kuroo & Gentianaceae & Rhizomes (roots) & Gentiopicrine, gentianic acid \\
\hline 17 & Gloriosa superba & Liliaceae & Rhizome, tuber, leaves, flower & $\begin{array}{l}\text { Choline, colchicine, stigmasterol, salicylic } \\
\text { acid, 2-methylcolchicine. }\end{array}$ \\
\hline 18 & Glycyrrhiza glabra & Papilionaceae & Roots, leaves. & $\begin{array}{l}\text { Genistein, eugenol, bergapten, glycyrrhizin, } \\
\text { acetophenone, estragole, camphor, ascorbic } \\
\text { acid, apigenin, anethole. }\end{array}$ \\
\hline 19 & $\begin{array}{l}\text { Gmelina arbórea } \\
\text { Roxb }\end{array}$ & Verbenaceae & Whole plant. & Betulin \\
\hline 20 & Grewia asiatica & Tiliaceae & Leaves, roots, fruits, bark. & Betulin \\
\hline 21 & $\begin{array}{c}\text { Hibiscus } \\
\text { rosa-Sinensis }\end{array}$ & Malvaceae & Buds, roots, leaves, flower & Quercetin, ascorbic acid. \\
\hline 22 & $\begin{array}{c}\text { Hygrophila } \\
\text { auriculata }\end{array}$ & Acanthaceae & Roots, leaves, seeds. & $\begin{array}{l}\text { Oleic and linoleic acids in seed oil, palmitic } \\
\text { acid, stearic acid. }\end{array}$ \\
\hline 23 & Manihot esculenta & Euphorbiaceae & Tuberous roots. & $\begin{array}{l}\text { Ascorbic acid, palmitic acid, lauric acid, } \\
\text { stearic acid, oleic acid. }\end{array}$ \\
\hline 24 & Martynia annua & Pedaliaceae & Fruits, leaves. & $\begin{array}{l}\text { Pelargonidin-3,5-diglucoside, } \\
\text { cyanidin-3-galactoside, semi-drying oil. }\end{array}$ \\
\hline 25 & Momordica charantia & Cucurbitaceae & Whole plant & $\begin{array}{l}\text { 5-Hydroxytryptamine, alkaloids, ascorbic } \\
\text { acid, } \beta \text {-carotene, cholesterol, lutein, } \\
\text { diosgenin, lanosterol, lycopene, momordicin, } \\
\text { charantin niacin, momordicoside. }\end{array}$ \\
\hline 26 & Moringa oleifera & Moringaceae & Roots, bark, leaves, seeds. & $\begin{array}{l}\text { Choline, moringinine, myristic, ascorbic acid, } \\
\beta \text {-carotene, niacin, oleic acid, spirochin, } \\
\text { stearic acid, tocopherol, vanillin. }\end{array}$ \\
\hline 27 & Nelumbo nucifera & Nymphaeaceae & Whole plant. & $\begin{array}{l}\text { Anonaine, ascorbic acid, } \beta \text {-carotene, copper, } \\
\text { erucic acid, glutathione, hyperoside, myristic } \\
\text { acid, nuciferine, oxoushinsunine, rutin, } \\
\text { stearic acid, trigonelline, } \\
\text { kaempferol, D-catechin. }\end{array}$ \\
\hline 28 & Nicotiana tobacum & Solanaceae & Leaves. & $\begin{array}{l}\text { 1,8-Cineole, 4-vinylguaiacol, acetaldehyde, } \\
\text { acetophenone, alkaloids, anabasine, nicotinic } \\
\text { acid, nicotine, scopoletin, quercitrin, sorbitol, } \\
\text { tocopherol stigmasterol, trigonelline. }\end{array}$ \\
\hline
\end{tabular}


Table 2. Cont

\begin{tabular}{|c|c|c|c|c|}
\hline Number & Botanical Name & Plant/Family & Parts Used & Constituent Compounds \\
\hline 29 & Nigella sativa & Ranunculaceae & Seeds. & $\begin{array}{l}\alpha \text {-spinasterol, ascorbic acid, } \beta \text {-sitosterol, } \\
\text { carvone, D-limonene, linoleic acid, myristic } \\
\text { acid, methionine, nigellone, stearic acid, } \\
\text { stigmasterol, tannin, } \\
\text { thymoquinone, hederagenin. }\end{array}$ \\
\hline 30 & Ocimum basilicum & Laminaceae & Whole plant & $\begin{array}{l}\text { Acetic acid, ascorbic acid, aspartic acid, } \\
\text { apigenin, arginine. }\end{array}$ \\
\hline 31 & Plumbago zeylanica & Plumbaginaceae & Root, leaves, root, bark. & $\begin{array}{l}\text { Plumbagin, droserone, 3-chloroplumbagin, } \\
\text { chitranone, zeylinone, } \\
\text { elliptione, isozeylinone. }\end{array}$ \\
\hline 32 & Portulaca oleraceae & Portulaceae & Stem, leaves, seeds. & $\begin{array}{l}\text { Oleracins I and II, acylated betacyanins, } \\
\text { carbohydrate, galacturonic acid, mucilage. }\end{array}$ \\
\hline 33 & $\begin{array}{l}\text { Pterocarpus } \\
\text { marsupium }\end{array}$ & Fabaceae & leaves, flower, gum Heartwood, & $\begin{array}{l}\text { Alkaloids, gum, essential oil, semi-drying } \\
\text { fixed oil. }\end{array}$ \\
\hline 34 & Solanum melongena & Solanaceae & Roots, leaves, tender fruits. & Ascorbic acid, alanine, arginine, caffeic acid. \\
\hline 35 & Solanum nigrum & Solanaceae & Whole plant. & Solenin, solasodine. \\
\hline 36 & $\begin{array}{l}\text { Stereopermum } \\
\text { suaveolens }\end{array}$ & Bignoniaceae & Roots, flower & $\begin{array}{l}\text { Mucilage, albumin, sugar, wax, lapachol, } \\
\text { dehydrotectol, } \beta \text {-sitosterol, } n \text {-triacontanol. }\end{array}$ \\
\hline 37 & Tephrosia purpurea & Fabaceae & Whole plant & Tephrosin, betulinic acid, lupeol, rutin. \\
\hline 38 & Terminalia chebula & Combretaceae & Mature, immature fruits. & $\begin{array}{l}\text { Ascorbic acid, gallic acid, ellagic acid, } \\
\text { chebulic acid. }\end{array}$ \\
\hline 39 & Thespesia populnea & Malvaceae & Whole plant & Gossypol, herbacetin, kaempferol. \\
\hline 40 & $\begin{array}{l}\text { Thespesia } \\
\text { populneoides }\end{array}$ & Malvaceae & Whole plant & $\begin{array}{l}\text { Populneol, gossypol, kaempferol, } \\
\text { quercetin-5-glucoside, calycopterin, } \\
\text { kaempferol-5-glucoside, } \\
\text { kaempferol-3-gluoside. }\end{array}$ \\
\hline 41 & Tinospora cordifolia & Menispemaceae & Stem & Alkaloids, starch. \\
\hline 42 & Vernonia cinerea & Asteraceae & Whole plant & Linoleic acid, lupeol, vernolic acid. \\
\hline
\end{tabular}

Other plant species with anti-inflammatory properties have already been described in the literature. However, the parts of the plants used and the compounds responsible for the anti-inflammatory activity have not yet been fully elucidated.

Phytochemical studies carried out with the species Myracroduo nurundeuva Allemão, Schinus terebinthifolius Raddi, Spondias mombin L., Spondias purpurea L. and Spondias tuberosa Arruda, belonging to the Anacardiaceae family, detected the presence of several secondary metabolites. The most abundant are phenols, triterpenes, flavonoids, and cinnamic acid, which are responsible for their anti-inflammatory action [53-55].

The plants that make up the Euphorbiaceae family, such as the species Euphorbiaceae acalypha hispida Burm. f., Acalypha indica L., Phyllanthus niruri L., are rich mainly in phenolic compounds, saponins, tannins, and triterpenes, which are responsible for their anti-inflammatory action [56-58].

Research with the species Ruellia asperula (Mart. Ex Ness) Lindau (family Acanthaceae), Achyranthes aspera L., Alternanthera brasiliana (L.) Kuntze (family Amaranthaceae), Himatanthus drasticus (Mart.) Plumel (family Apocynaceae), Matricaria chamomilla L. (family Asteraceae), Heliotropium indicum L. (family Boraginaceae), Momordica charantia L. (family Cucurbitaceae), Mimosa tenuiflora (Willd.) Poir (family Leguminosae), Borreria verticillata (L.) G.Mey. (family Rubiaceae), Solanum paniculatum L. (family Solanaceae), and Zingiber officinale Roscoe (family Zingiberaceae) also indicates the existence of compounds with anti-inflammatory activity [59-63].

It is important to note that the extraction of plant materials is the first major step to test biological activities, presenting many advantages and some disadvantages compared to the isolation of pure active compounds [50]. When an entire extract is used, there is a good chance of synergism between active components that can be lost when each of these components is isolated. This synergism was discovered in several medicinal tests, including those for anti-inflammatory activity. On the contrary, the mixture of different compounds together may also lead to inhibitory effects, namely, that one component may reduce the biological activity of the other. In line with this assumption, some studies have shown that the anti-inflammatory activity of pure compounds (such as amentoflavone, pseudohypericin, and hyperforin) is higher than that of the extracts $[50,64,65]$. 
Medicinal plants are used instead of Non-steroidal anti-inflammatory drugs (NSAIDs) as the use of non-steroidal anti-inflammatory drugs is associated with several side effects, among which are unwanted effects on the gastrointestinal tract and the renal system. The biggest disadvantage of recently available potent synthetic drugs is concerning their toxicity and the reappearance of symptoms after discontinuation. Therefore, the screening and development of drugs with anti-inflammatory activity are necessary and there are many efforts to find anti-inflammatory drugs from medicinal plants [7].

Inflammation is a huge challenge for human kind. Although many anti-inflammatory drugs are available, it is believed that these drugs, such as opioids and analgesia inducing drugs like NSAIDs, are not useful in all cases and these drugs also produce side effects, so to overcome these problems, new drug molecules need to be discovered from plants. Plants have many phytoconstituents helpful in reducing inflammation and fewer side effects [7].

The objectives of the use of plants as therapeutic agents are: to concentrate and/or isolate bioactive substances for direct use as drugs; to produce bioactive compounds of novel or already known structures for semi synthesis to produce patentable entities of higher activity and/or lower toxicity; to use agents as pharmacological tools; and to use the whole plant or part of it as a herbal remedy [66].

It is worth mentioning that for the acquisition of new drugs, molecular diversity and biological function distinguish products of natural origin from synthetic products. The molecular diversity of natural products is far superior to that derived from synthesis processes, which, despite technological advances, are still restricted. This fact makes it possible for the chemical compounds present in plants to become potential drugs for different diseases [19].

An example of a phytotherapeutic anti-inflammatory agent is Acheflan ${ }^{\circledR}$, indicated for the local treatment of inflammatory processes, and Daflon $500 \mathrm{mg}{ }^{\circledR}$, a drug composed of a purified flavonoid fraction that presents venotonic and vasoprotective action [37]. Therefore, the study of the immunopharmacological activities of plant species has provided evidence on different extracts/fractions and chemical classes with high therapeutic potential, which represents a promising alternative to the inflammatory processes and diseases related to them, as well as a form of validation of their ethnobotanical use. Besides, data from the scientific literature have shown that molecules of plant origin present important anti-inflammatory activities and that many of their actions are related to the ability to inhibit the synthesis or action of cytokines, chemokines, and adhesion molecules, and arachidonic acid and nitric oxide pathways $[67,68]$.

\section{Secondary Metabolite Biosynthesis}

Secondary metabolism is a set of reactions that have important biosynthetic intermediates, derived from biochemical processes that make up the primary glucose metabolism: such as glycolysis, the pentose pathway, the Krebs cycle, and photosynthesis. The main intermediates are shikimic acid, acetyl-coenzyme A (acetyl-CoA), and 1-deoxyxylulose 5-phosphate [69].

Shikimic acid is synthesized from a combination of phosphoenolpyruvate (via glycolysis) with 4-phosphate erythrosis (pathways pentoses or photosynthesis) and is a precursor to hydrolyzabletannins, coumarins, alkaloids derived from aromatic amino acids and phenylpropanoids, compounds that have the presence of an aromatic ring in common. These compounds are produced by the biochemical route called the shikimate pathway [70].

Acetyl-CoA is formed by oxidative decarboxylation of pyruvic acid (glycolysis) and its derivatives are fatty acids and polyketides; in turn, three acetyl-CoA molecules constitute mevalonic acid and 1-deoxyxylulose 5-phosphate originates from the combination of pyruvic acid and glyceraldehyde-3-phosphate (two intermediates of glycolysis); 1-deoxyxylulose 5-phosphate, together with mevalonic acid, are precursors to several terpenoids and steroids [71].

The secondary compounds produced from these intermediates are synthesized by biosynthetic routes called the acetate pathway, the mevalonate pathway, and the deoxyxylulose phosphate (DXP) pathway [72,73]. Through the acetate pathway, compounds called polyketides are formed (by the 
condensation of acetic acid units, giving rise to poly- $\beta$-keto chains). In this class are fatty acids, polyacetylenes, prostaglandins, macrolide antibiotics, and various aromatic compounds, such as anthraquinones and tetracyclines [74,75].

Other compounds such as some flavonoids and alkaloids are formed by a mixed route, that is, they have reaction intermediates from the acetate pathway and the shikimate pathway.

The mevalonate and deoxyxylulose phosphate pathways comprise the so-called terpenoids, steroids, triterpene and steroidal saponins, cardiotonic glycosides. Terpenoids are synthesized through the mevalonate pathway, in the cytoplasm [76].

Besides, the cycloartenol tetracyclic ring system is a precursor to many plant sterols. Modifications and substitutions that occur lead to the formation of a wide variety of compounds of natural origin, which present several important biological activities such as, for example, sterols, steroidal saponins, cardioactive glycosides, bile acids, corticosteroids, and mammalian sex hormones. The differences in biological activities presented by these compounds, which contain the tetracyclic skeleton in common, are attributed to the functional groups linked to the steroid nucleus, and to the stereochemical variations of that nucleus [77].

Saponins are glycosides of steroids or polycyclic terpenes. For aglycone, they are called steroidal saponins and triterpene saponins. Tripterpenic saponins correspond to a triterpenoid carbon skeleton pentacyclic, formed by the epoxidation and cyclization of squalene, in the conformation chair-chair-chair, and then carboxylations, oxidations, oxidation of methyl groups, the appearance of formyl (-CHO) or hydroxymethyl $\left(-\mathrm{CH}_{2} \mathrm{OH}\right)$ groups may occur [76].

The shikimate pathway is used only by microorganisms and plants and is a pathway for the synthesis of aromatic compounds, particularly aromatic amino acids: L-phenylalanine, L-tyrosine, and L-tryptophan. This pathway starts with phosphoenolpyruvate (from glycolysis) and D-erythrose phosphate (from the pentose pathway or photosynthesis), forming the shikimic acid and this, in turn, gives rise to aromatic compounds. The amino acids phenylalanine and tyrosine form phenylpropane, which is a basic unit present in many natural products (cinnamic acid, phenylpropanoids, coumarins, lignans, and flavonoids) and, together with tryptophan, are precursors to a wide range of alkaloid structures [74].

Phenylpropanoids are also derived from the route that begins with the formation of shikimic acid, giving rise to phenylalanine and tyrosine which, in turn, by the action of the enzyme phenylalanine ammonialyase, lose an ammonia molecule, resulting in the formation of cinnamic and 4-cumáric acids, respectively, and, through various reactions of reduction, oxidation, and cyclization give rise to several phenylpropanoids. Coumarins are derived from the metabolism of phenylalanine, one of its first precursors being 2-coumaric acid (orthohydroxy-cinnamic), which then undergoes lactonization of the side chain, giving rise to coumarin. Xanthones are heterocyclic phenolic compounds, which are based on the dibenzo- $\gamma$-pyrone nucleus. The biosynthesis of xanthones in higher plants is well determined, following the acetate-shikimate pathway. From two precursors, the formation of a common intermediate, a benzophenone, occurs with an aromatic ring originating from the shikimic acid route (B), which can characteristically contain hydroxyl groups in C5 and/or C7, and another from the malonyl-CoA route (THE) [78].

Chromones are heterocyclic compounds, which consist of the fusion of a benzene ring with a pyrone ring. The simplest compound in this family is the chromone itself (4H-chromen-4-one, 4H-1-benzopyran-4-one). The most abundant natural chromones are those that have substituents in the $\mathrm{C} 2$ and $\mathrm{C} 3$, by another benzene ring, being called flavones and isoflavones, respectively, and for this reason, their inclusion in the group of flavonoids is recurrent. These compounds constitute an important set of biologically active substances, mostly of natural origin, being present in great abundance in the plant kingdom [79].

Flavonoids are a class of polyphenolic compounds that differ from each other according to their chemical structure and particular characteristics. The biosynthesis of these compounds occurs through a via mist, between the shikimic acid and acetate pathways. Shikimic acid is the precursor to the starting 
compound for the synthesis of flavonoids, phenylalanine. After being deaminated by phenylalanine amonialiasis, this aromatic amino acid produces cinnamic acid, which by the action of 4-hydroxylase cinnamate is converted into p-coumaric acid (4-cumharic) [75].

Thus, in flavonoids, ring $\mathrm{A}$ is formed via acetate, while B results from the shikimate route and the three carbon atoms, which link ring A to B, derived from phenylpyruvate. Flavonoids can occur as aglycone or glycosides (a glucose molecule attached to the aromatic ring). The compounds belonging to this class are subdivided into subclasses: chalcones, dihydrochalcones, aurone, flavones, flavonols, dihydroflavonoids, flavanones, flavanol, flavandiol, anthocyanidins, isoflavonoids, bioflavonoids, and proanthocyanins. Chalcones are precursors to many derivatives of flavonoids, found throughout the plant kingdom, such as flavonones, and these, in turn, can then give rise to many other flavonoids, such as, for example, flavones, flavonols, anthocyanidins, and catechins. Other compounds can be formed by changes in hydroxylation, methylation, glycosylation, and dimethyl allylation in the two aromatic rings [75].

Anthraquinones are also called anthracenedione, anthracene derivatives, or hydroxyanthracene derivatives. The biosynthesis of these compounds has shikimic acid and acetate, or just acetate as precursors, and in the first case, shikimic acid reacts with $\alpha$-ketoglutaric acid, resulting from the deamination of acid glutamic or the citric acid cycle, producing o-succinylbenzoic acid, 1,4-dihydroxy-2-naphthoic acid combines with mevalonic acid, giving rise to anthraquinone [74].

Tannins are a class of phenolic compounds of great complexity and importance. They are classified, according to their chemical structure, into two groups: hydrolyzable and condensed [77]. Gallic acid is a benzoic acid, derived from cinnamic acid, derived from the shikimate pathway. Gallic acid reacts with ureadin diphosphate-glucose (UDP-glucose), forming the intermediate $\beta$-glycocalin, which gives rise to 1,2,3,4,6-pentagaloyl-D-glucose, a molecule that, after oxidative transformations, leads to the formation of galotanins and ellagitannins [74].

There are three routes of biosynthesis of hydrolyzabletannins: in the first route, the addition of galloyl groups to 1,2,3,4,6-pentagaloyl-D-glucose is used, through $m$-depisidic bonds. In the second route, two neighboring gallic acid molecules (1,2,3,4,6-pentagaloyl-D-glucose) condense, and then this compound (monomer) can bind to others, forming dimers, trimers, and oligomers. Condensed tannins or proanthocyanidins are polymers of flavan-3-ol and/or flavan-3,4-diol (leukocyanidins), products of shikimate metabolism and acetate pathway (as seen in flavonoids). Dihydroflavonols are reduced to leucoanthocyanidins, which in turn give rise to catechins, which suffer a reduction in C4. Proanthocyanidins (condensed tannins) are probably caused by a condensation reaction between leucoanthocyanidins and catechins [74].

The biosynthesis of alkaloids always includes at least one amino acid, to these amino acids are also incorporated into other units from pyruvate, malonate, or mevalonate [80].

Thus, with such distinct precursors of biosynthetic origin, it is easy to understand the complexity and structural diversity of this class of metabolites, with more than 5000 alkaloids known today. Alkaloids are classified according to the amino acid that provides both the nitrogen atom and the fundamental part of the molecule's skeleton. The aromatic amino acids histidine, tryptophan, tyrosine, and phenylalanine give rise to alkaloids with indole, isoquinolinic nuclei and anthranilic acid gives rise to quinolinic, quinazolinic, benzoxazinic alkaloids [74].

\section{Anti-Inflammatory Molecules of Medicinal Plants and Mechanism of Action}

Substances of plant origin, belonging to the most diverse chemical classes, have already demonstrated proven anti-inflammatory activity [9]. Among them, alkaloids, terpenes [81-84], and phenolic compounds such as tannins, lignans, coumarins, saponins, and especially the flavonoids stand out [83-89] (Figure 1). 


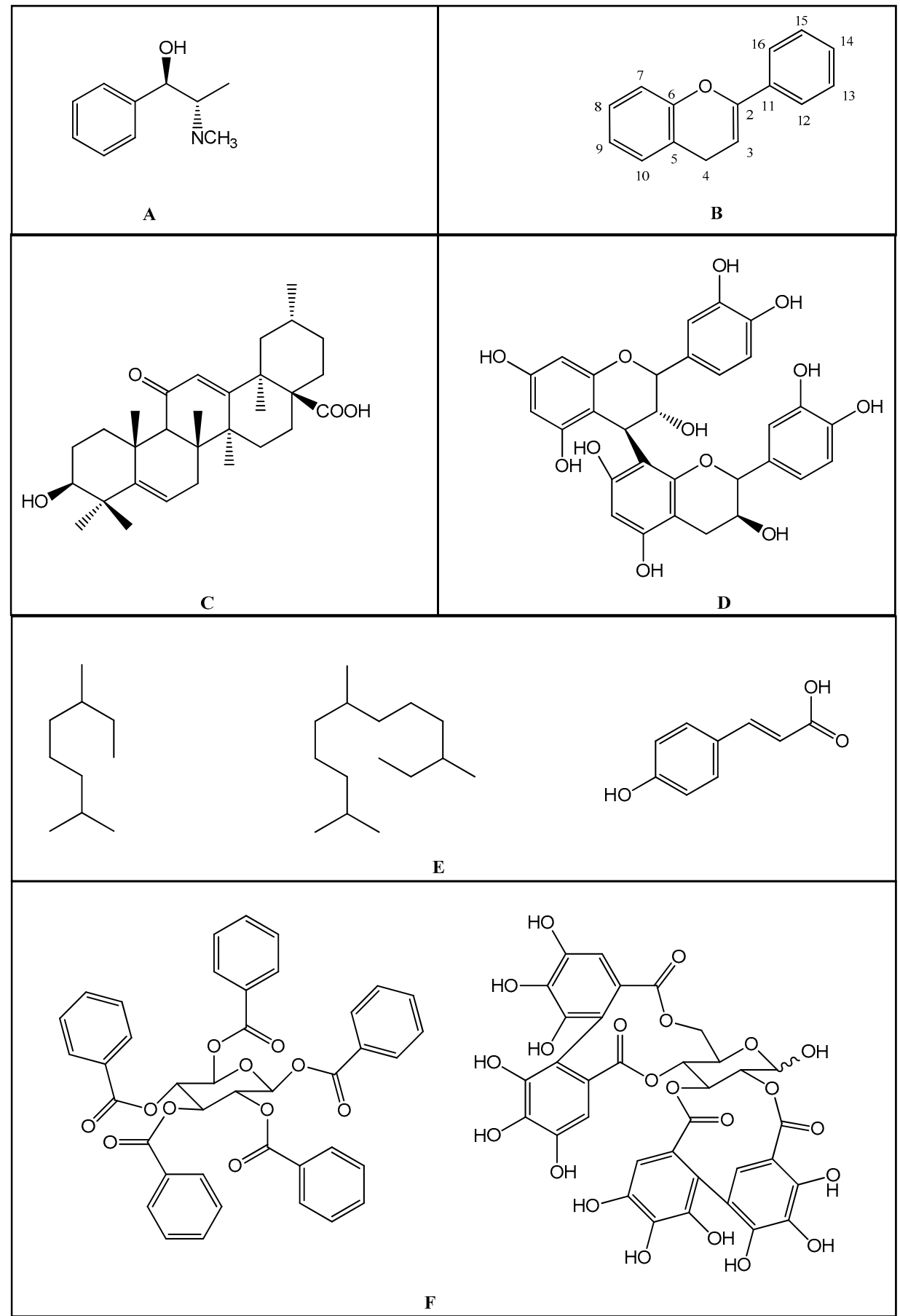

Figure 1. (A): Chemical structure of alkaloids: Ephedrine. (B): Basic Flavonoid Structure, (C): Chemical structure of saponins: Glycyrrhizin, (D): Structure of condensed tannin, (E): Structure of terpenoids and phenylpropanoids, (F): Structure of hydrolysable tannins: Galotannins and Ellagitannins [74,90].

The flavonoids represent a group of vegetal pigments with extensive distribution in nature, being available in fruits, seeds, flowers, and barks [91,92]. Their basic structure is the flavan nucleus, which consists of 15 carbon atoms arranged in 3 rings (C6-C3-C6) which are labeled as A, B, and C. Figure 1 presents the structure of the flavonoids and their numbering to distinguish the position of the carbons around the molecule [74].

The structural variation in ring $\mathrm{C}$ subdivides flavonoids into six main subclasses: flavonols (e.g., quercetin, kaempferol, myricetin), flavones (e.g., luteolin, apigenin), flavanols (e.g., catechin), 
flavanones (e.g., hesperetin), anthocyanidins (e.g., cyanidin, pelargonidin), and isoflavones (e.g., genistein, daidzein) [93].

Flavonoids have an anti-inflammatory capacity since they inhibit the production of inflammatory mediators by modulating the arachidonic acid pathway, inhibiting several enzymes such as ATPase, prostaglandin, cyclooxygenase, lipoxygenase, NADH oxidase, protein kinase, hydrolases, peroxidases, metallopeptidases, tyrosinases, and phospholipases. Thus, flavonoids have been the target of increasing interest as a potential therapeutic drug in inhibiting or even decreasing inflammatory activity [88,91].

Although an expressive number of flavonoids are present in plants in the form of glycosides, consignments about the biological activities of flavonoids have been made mainly for aglycones. Some research on the structure-activity relationship and the inhibition of inflammatory mediators can also be found in the scientific literature. It has been reported that the presence of hydroxylations at the $3^{\prime}$ and $4^{\prime}$ positions of the B ring of the flavonoid structure enhances the modulatory action on the inhibitory activity of TNF- $\alpha$ [94], while the presence of only one hydroxyl minimizes inhibition and the absence of this group overrides the inhibitory effect. To inhibit iNOS or nitric oxide (NO) production, the presence of at least three hydroxyls is required [95]. This is the case of luteolin and its derivatives that have a catecholic pattern of oxygenation in ring B and also oxygenations in ring A. Oxygenation at position 5 of ring A contributes significantly to anti-inflammatory activity [96].

The anti-inflammatory potential of 9 flavonoid aglycones was evaluated: kaempferol, quercetin, apigenin, chrysin, diosmetin, luteolin, daidzein, genistein, and hesperetin. Among them, luteolin was the most active in the inhibition of NO and TNF- $\alpha$ [95].

Quercetin is found in high concentrations in plants such as Allium cepa, Camellia sinensis, Hypericum perforatu, and Podophyllum peltatum. This compound acts by promoting a significant reduction in edema volume in both acute and chronic models; with effects comparable to those of phenylbutazone [50].

The flavonoids rutin, quercetin, and hesperidin were found to have anti-inflammatory effects. Plants such as onions (Allium cepa) contain a high concentration of quercetin and studies confirmed the anti-inflammatory activities of onion juice and extracts. Abutilon indicum also contains high amounts of quercetin and has significant anti-inflammatory activity. Besides, garlic contains large amounts of allicin which exerts potent anti-inflammatory effects [97-99].

Investigations involving kaempferol, quercetin, and aromadendrene glycosides and their anti-inflammatory activity due to suppression of NO levels in LPS-stimulated microglial cells indicated that glycosylation attenuated the aglycone suppressor activity. Although attenuated, some of the glycosides, depending on the position and degree of glycosylation, retained the inhibitory capacity of NO production, which suggests that the glycosylation of flavonoids should be considered as an important modulator of biological activity [100].

Although other authors have shown that the glycosidic portion of biologically active substances may be a crucial factor for their biological activity, in many situations, glycosylation only improves pharmacokinetic parameters [101]. The presence of methoxyl as substituents in flavonoids may considerably interfere with their anti-inflammatory activity; 41 synthetic chalcones were studied, verifying that the most active structures have a methoxyl in the position adjacent to a carbonyl [102].

Another group of compounds known for their anti-inflammatory activity is alkaloids. They usually contain nitrogen in a heterocyclic ring, in a state of negative oxidation, with an amine group that gives them a basic character [103]. The alkaloids are classified according to the nature of the nitrogen atom present in their structure. Alkaloids that have a nitrogen atom in a heterocyclic ring are called true alkaloids. Substances with nitrogen atoms not belonging to a heterocyclic ring are called protoalkaloids and substances with and without heterocyclic rings that are not derived from amino acids are called pseudoalkaloids [82].

Alkaloids can also be classified according to their biogenetic precursors, which confer their structural characteristics, such as indole alkaloids. Alkaloids are derived from amino acids such as ornithine, lysine, tyrosine, and tryptophan. Ornithine is a precursor for pyrrolidine and tropic alkaloids, 
while lysine gives the piperidine alkaloids. Tyrosine and tryptophan are formed by the shikimic acid pathway and originate the isoquinolinic and indole alkaloids respectively [104]. Alkaloids are considered the most toxic among the several active principles. Some are known and used in scientific therapy, such as morphine, ergotamine, and ephedrine [105].

Saponins, such as glycyrrhizin, on the other hand, are steroid glycosides or polycyclic terpene used for the synthesis of cortisone (anti-inflammatory) and sex hormones. They increase the uptake and use of certain minerals [106] and can form complexes with steroids, proteins, and membrane phospholipids determining important biological properties such as changes in cell membrane permeability [77].

There is also the class of tannins. Plants that have a high tannin content are used in traditional medicine for the treatment of various diseases such as diarrhea, high blood pressure, rheumatism, wounds, kidney, and urinary problems, and inflammatory processes. The pharmacological activities of tannins are due to their high complexity with metallic ions (iron, manganese, copper, and others), antioxidant activity, and the ability to complex with other molecules such as proteins and polysaccharides [107].

The tannins are classified into two main groups, whose structures are very different from each other, although all of them have in the molecule polyhydroxyphenols or their derivatives. Those belonging to the first group are called hydrolysable tannins, which include galotannins and ellagitannins, polymers derived from gallic and ellagic acids [108].

The constituents of the second group are called condensed tannins. They are found in greater proportions and importance in food. At higher concentrations, they give fruits and other food astringent characteristics [109].

There are also terpenes, which exhibit pharmacological properties, such as anti-inflammatory and antinociceptive, inhibit platelet aggregation, and interfere at an intracellular level in several steps of the transduction mechanism. The chemical components of volatile oils can be divided into two groups: terpenoid derivatives (representing the union of two, three, or more isoprene units) formed by the mevalonic acid-acetate route, and the phenylpropanoid derivatives, aromatic compounds formed by the shikimic acid pathway [110].

Triterpenes such as $\alpha / \beta$-amyrin acetate, nimbin, filicene, and oleanolic acids are found in high concentrations in plants such as Thymus serpyllum, Syzygium aromaticum, Salvia triloba, Rosmarinus officinalis, Origanum majorana, Ligustrum lucidum, Lavandula latifolia. These compounds act by promoting a significant reduction in the volume of edema; effects comparable to those of hydrocortisone. Besides, several terpenes and polyphenols have been identified in high concentrations in Nepenthes mirabilis (Lour.) Rafarin (a carnivorous plant), promoting a significant reduction in the levels of IL-6, IL-12, and TNF- $\alpha$ [50].

Several pathologies, such as the inflammatory process, can be aggravated by the formation of free radicals and generate tissue lesions by promoting oxidation [111]. It is well-known that oxidative stress plays important role in endothelial dysfunction, lung disease, gastrointestinal dysfunction, and atherosclerosis, and inflammatory symptoms are involved in all these disorders [112,113]. Excessive pro-inflammatory cytokines and mitochondrial dysfunction induce oxidative stress, characterized by an imbalance between the effectiveness of antioxidant defense and the speed of ROS generation, causing a net overload of oxidants [114-116].

Antioxidant compounds may reduce oxidative stress, minimizing the incidence of these pathologies. The search for new antioxidant agents from plant sources used in the human diet and folk medicine against inflammation and infection may lead to the discovery of natural molecules with high anti-inflammatory potential in vitro and in vivo. These substances could justify the popular use of these plant species with anti-inflammatory properties [117].

Free radicals are organic or inorganic molecules that have atoms that contain one or more unpaired electrons [118]. The majority of free radicals observed are superoxide $\left(\mathrm{O}_{2}^{-}\right)$, hydroxyl $\left(\mathrm{OH}^{-}\right)$, hydroperoxide $\left(\mathrm{HO}_{2}^{-}\right)$, nitric oxide $(\mathrm{NO})^{\bullet}$, and nitrogen dioxide $\left(\mathrm{NO}_{2}{ }^{\bullet}\right)$. Among these, the hydroxyl 
radical is the most reactive in the induction of cellular lesions and hydrogen peroxide can cross the nuclear membrane and induce damage in the DNA molecule $[119,120]$.

Free radicals induced by peroxidation are implicated in the pathogenesis of chronic inflammation that can trigger various pathological conditions such as arthritis and cancer, among others [121]. It is important to mention that inflammation has been linked to an increased risk for the development of different types of tumors such as gastric mucosal lymphoma, colon cancer, gastric cancer, and prostate cancer. Many factors lead to chronic inflammation such as microbial infections, autoimmune diseases, inflammatory conditions, physical injuries, or chemical compounds, such as free radicals [122]. Besides, inflammatory processes also promote an increase in the concentration of free radicals in the body [123].

Lipid peroxidation is the process by which reactive oxygen species (ROS) attack the polyunsaturated fatty acids of the phospholipids of cell membranes, disintegrating them and allowing the entry of these species into intracellular structures. In this scenario, phospholipase that has been activated by toxic species disintegrates the phospholipids and this causes the release of unsaturated fatty acids. As in the formation of ROS, the processes of lipo peroxidation are not always harmful, since their products are significant in the cascade reaction from arachidonic acid and, therefore, in the inflammatory response. Research has shown that flavonoids inhibit lipid peroxidation, in vitro, in the initiation stage, due to its action as an antioxidant [124].

In this context, inflammation is clinically defined as a pathophysiological process characterized by redness, increased heat, swelling, pain, and loss of function. These signs occur as a response of the organism to the invasion of infectious agents or physical injury. Both the innate immune response and acquired are involved in the inflammatory process, generating numerous local and systemic effects. Depending on the time of evolution, it can be acute or chronic, although sometimes the conventional patterns cannot detect a previous event $[125,126]$. The innate immune system is the foremost defense mechanism against invading microorganisms and cancer cells, involving the activity of various cells including macrophages, mast cells, and dendritic cells. The adaptive immune systems involve the activity of more specialized cells such as $\mathrm{B}$ and $\mathrm{T}$ cells which are responsible for eradicating invading pathogens and cancer cells by producing specific receptors and antibodies [50].

During the inflammatory process, vascular and chemical events are identified [127,128]. Vascular events occur in the microcirculation, causing several modifications such as elevation of blood flow and capillary permeability, among others. These alterations are local effects of chemical mediators, which are plasma enzyme systems, cytokines, mast cell products, platelets, leukocytes, and products of arachidonic acid metabolism $[128,129]$. Thus, the inflammation events that underlie these manifestations are induced and regulated by a large number of chemical mediators, including kinins, eicosanoids, complement proteins, histamine, and monokines [7].

During the inflammatory process, short-term and rapid-onset reactions lasting 1 to 2 weeks, belonging to the group of acute inflammation, may be recognized. On the other hand, reactions that persist for longer than months or years and that have a slow and insidious speed, belong to the group of chronic inflammation [130]. Both can be restricted to local phenomena or involve systemic phenomena. The characteristics, extent, and severity of the inflammatory process depend on factors related to the host (nutritional status and genetic factors) and the nature and pathogenicity of the aggressor agent [92].

Flavonoids also act by modulating the induced nitric oxide synthase enzyme and the cells involved with inflammation, inhibiting the production of proinflammatory cytokines and modulating the activity of arachidonic acid pathways, such as cyclooxygenase (COX), lipoxygenases (LOX), and phospholipase A2 [131].

Phospholipases A2 (PLA2) formsone of the main groups of mediators of the inflammatory process, through the production of arachidonic acid. By inhibiting the action of phospholipase, the onset of the inflammatory process is inhibited. Besides, free arachidonic acid can be metabolized to various lipid mediators known as eicosanoids via the lipoxygenases and cyclooxygenase pathways [132,133]. 
Furthermore, arachidonic acid can be metabolized to prostaglandins and epoxyeicosatrienoic acids by cyclooxygenase-2 (COX-2) and cytochrome P450 (CYP), respectively [114,134,135].

Thus, arachidonic acid metabolites play a vital role in inflammation. In inflammatory conditions, arachidonic acid is released from membrane phospholipids by the enzyme phospholipase A2 and metabolized by cyclooxygenases, lipoxygenases, and cytochrome P450s (CYPs) to prostaglandins/thromboxane, leukotrienes, and epoxy/hydroxy-metabolites such as epoxyeicosatrienoic acids and other EpFAs, respectively $[114,136,137]$. Cyclooxygenase (COX), an enzyme responsible for the generation of prostaglandins (PG) from arachidonic acid, which is released from phospholipids of the cell membrane by phospholipase, has an induced form (COX-2) and a constitutive form (COX-1) [114].

COX-1 is essential for maintaining the normal physiological state of many tissues, including the protection of the gastrointestinal mucosa; control of renal blood flow; homeostasis; autoimmune responses; pulmonary and central nervous system functions; and cardiovascular and reproductive diseases [30]. COX-1 stimulus regulates the normal physiological processes, being responsible for the synthesis of prostaglandins.

In contrast, COX-2 is not detectable in tissues under normal physiological conditions, but its expression increases considerably during inflammation or mitogenic stimulation [138]. COX-2, induced in inflammation by various stimuli-such as cytokines, endotoxins, and growth, gives rise to prostaglandins, which contribute to the development of edema, flushing, fever, and hyperalgesia [30]. Thus, COX-2 is inducible or regulated by inflammatory stimuli, such as interleukin- $1 \mathrm{~b}$, tumor necrosis factor, and lipopolysaccharide. This enzyme is associated with the production of prostaglandin E2 and prostacyclin that evoke peripheral and systemic inflammatory symptoms [32-35].

Therefore, the activation of these enzymes stimulates intracellular signals (NFkB, p38 or MAPKs, which modify the expression of pro-inflammatory cytokines, for example, interleukin 1 beta (IL1b), interleukin 6 (IL6), and tumor necrosis factor-alpha (TNF- $\alpha$ ) adhesion proteins and chemokines, leading to stimulation and activation of immune cells [122]. Thus, the metabolites of COX-2 are involved in inflammatory disorders. Studies indicate that inhibition of COX-2 or soluble epoxidehydrolase is beneficial for inflammation [114,139-147].

In 2002, a new isoform was discovered: COX-3 [38,138,148]. Therefore, many researchers focus on the development of new and selective inhibitors of pro-inflammatory enzymes and cytokines [149]. However, it remains poorly characterized [30].

Inhibition of COX has been considered an important target of possible drugs for the treatment of inflammation [35]. Inhibition of COX by agents such as acetylsalicylic acid seems to be responsible for the lack of balance of arachidonic acid metabolites, raising the products derived from lipoxygenase, leukotrienes, with bronchoconstriction and proinflammatory properties [150].

Thus, it is important to note that the successful development of new naturally occurring anti-inflammatory drugs depends mainly on a multidisciplinary effort to find new molecules due to the existence of a large number of species available for research.

Funding: This research was funded by Fundação Carlos Chagas Filho de Amparo à Pesquisa do Estado do Rio de Janeiro-FAPERJ (E-26/010.001802/2015).

Conflicts of Interest: The authors declare no conflict of interest.

\section{References}

1. Corlett, R.T. Plant diversity in a changing world: Status, trends, and conservation needs. Plant. Divers. 2016, 38, 10-16. [CrossRef] [PubMed]

2. $\quad$ Laurance, W.F.; Useche, D.C.; Rendeiro, J.; Kalka, M.; Bradshaw, C.J.A.; Sloan, S.; Laurance, S.G.; Campbell, M.; Abernethy, K.; Álvarez, P.; et al. Averting biodiversity collapse in tropical forest protected areas. Nature 2012, 489, 290-294. [CrossRef] [PubMed]

3. Souza, R.K.D.; Mendonça, A.C.A.M.; Silva, M.A.P. Ethnobotanical, phytochemical and pharmacological aspects Rubiaceae species in Brazil. Rev. Cubana Plant Med. 2013, 18, 140-156. 
4. Shazhni, J.A.; Renu, A.; Vijayaraghavan, P. Insights of antidiabetic, anti-inflammatory and hepatoprotective properties of antimicrobial secondary metabolites of corm extract from Caladium $x$ hortulanum. Saudi J. Boil. Sci. 2018, 25, 1755-1761. [CrossRef] [PubMed]

5. Cao, Z.; Deng, Z. De Novo Assembly, Annotation, and Characterization of Root Transcriptomes of Three Caladium Cultivars with a Focus on Necrotrophic Pathogen Resistance/Defense-Related Genes. Int. J. Mol. Sci. 2017, 18, 712. [CrossRef]

6. Locatelli, C.; Nardi, G.M.; Anuário, A.d.F.; Freire, C.G.; Megiolaro, F.; Schneider, K.; Perazzoli, M.R.A.; Nascimento, S.R.D.; Gon, A.C.; Mariano, L.N.B.; et al. Anti-inflammatory activity of berry fruits in mice model of inflammation is based on oxidative stress modulation. Pharmacogn. Res. 2016, 8, S42-S49. [CrossRef]

7. Virshette, S.J.; Patil, M.K.; Somkuwar, A.P. A review on medicinal plants used as anti inflammatory agents. J. Pharmacogn. Phytochem. 2019, 8, 1641-1646.

8. Liu, C.H.; Abrams, N.; Carrick, D.M.; Chander, P.; Dwyer, J.; Hamlet, M.R.J.; Macchiarini, F.; Prabhudas, M.; Shen, G.L.; Tandon, P.; et al. Biomarkers of chronic inflammation in disease development and prevention: Challenges and opportunities. Nat. Immunol. 2017, 18, 1175-1180. [CrossRef]

9. Fialho, L.; Cunha-E-Silva, J.A.; Santa-Maria, A.F.; Madureira, F.A.; Iglesias, A.C. Comparative study of systemic early postoperative inflammatory response among elderly and non-elderly patients undergoing laparoscopic cholecystectomy. Rev. Col. Bras. Cir. 2018, 45, e1586. [CrossRef]

10. Jang, C.H.; Kim, Y.Y.; Seong, J.Y.; Kang, S.H.; Jung, E.K.; Sung, C.M.; Kim, S.B.; Cho, Y.B.; Sung, J.Y. Clinical characteristics of pediatric external auditory canal cholesteatoma. Int. J. Pediatr. Otorhinolaryngol. 2016, 87, 5-10. [CrossRef]

11. Kim, Y.; Bayona, P.W.; Kim, M.; Chang, J.; Hong, S.; Park, Y.; Budiman, A.; Kim, Y.-J.; Choi, C.Y.; Kim, W.S.; et al. Macrophage Lamin A/C Regulates Inflammation and the Development of Obesity-Induced Insulin Resistance. Front. Immunol. 2018, 9, 1-14. [CrossRef] [PubMed]

12. Purohit, S.; Sharma, A.; Zhi, W.; Bai, S.; Hopkins, D.; Steed, L.; Bode, B.; Anderson, S.W.; Reed, J.C.; Steed, R.D.; et al. Proteins of TNF- $\alpha$ and IL6 Pathways Are Elevated in Serum of Type-1 Diabetes Patients with Microalbuminuria. Front. Immunol. 2018, 9, 154. [CrossRef] [PubMed]

13. Clark, M.; Kroger, C.J.; Tisch, R.M. Type 1 Diabetes: A Chronic Anti-Self-Inflammatory Response. Front. Immunol. 2017, 8, 1-10. [CrossRef] [PubMed]

14. Espigol-Frigole, G.; Planas-Rigol, E.; Lozano, E.; Corbera-Bellalta, M.; Terrades-García, N.; Prieto-González, S.; García-Martínez, A.; Hernández-Rodríguez, J.; Grau, J.M.; Cid, M.C. Expression and Function of IL12/23 Related Cytokine Subunits (p35, p40, and p19) in Giant-Cell Arteritis Lesions: Contribution of p40 to Th1and Th17-Mediated Inflammatory Pathways. Front. Immunol. 2018, 9, 1-11. [CrossRef]

15. Donninelli, G.; Del Cornò, M.; Pierdominici, M.; Scazzocchio, B.; Varì, R.; Varano, B.; Pacella, I.; Piconese, S.; Barnaba, V.; D'Archivio, M.; et al. Distinct Blood and Visceral Adipose Tissue Regulatory T Cell and Innate Lymphocyte Profiles Characterize Obesity and Colorectal Cancer. Front. Immunol. 2017, 8, 643. [CrossRef]

16. Katare, P.B.; Bagul, P.K.; Dinda, A.K.; Banerjee, S.K. Toll-Like Receptor 4 Inhibition Improves Oxidative Stress and Mitochondrial Health in Isoproterenol-Induced Cardiac Hypertrophy in Rats. Front. Immunol. 2017, 8, 719. [CrossRef]

17. Mozos, I.; Malainer, C.; Horbańczuk, J.; Gug, C.; Stoian, D.; Luca, C.T.; Atanasov, A.G. Inflammatory Markers for Arterial Stiffness in Cardiovascular Diseases. Front. Immunol. 2017, 8, 1058. [CrossRef]

18. Qi, H.; Yang, S.; Zhang, L. Neutrophil Extracellular Traps and Endothelial Dysfunction in Atherosclerosis and Thrombosis. Front. Immunol. 2017, 8, 928. [CrossRef]

19. Li, Y.; Kong, D.; Fu, Y.; Sussman, M.R.; Wu, H. The effect of developmental and environmental factors on secondary metabolites in medicinal plants. Plant. Physiol. Biochem. 2020, 148, 80-89. [CrossRef]

20. Zaynab, M.; Fatima, M.; Abbas, S.; Sharif, Y.; Umair, M.; Zafar, M.H.; Bahadar, K. Role of secondary metabolites in plant defense against pathogens. Microb. Pathog. 2018, 124, 198-202. [CrossRef]

21. Thumann, T.A.; Pferschy-Wenzig, E.-M.; Moissl-Eichinger, C.; Bauer, R. The role of gut microbiota for the activity of medicinal plants traditionally used in the European Union for gastrointestinal disorders. J. Ethnopharmacol. 2019, 245, 112153. [CrossRef] [PubMed]

22. Lima, A.S.; Alvim, H.G.O. Review on non-steroid antiinflammatory: Acetylsalicylic acid. Rev. Inic. Ciente. Ext. 2018, 1, 169-174.

23. Pereira-Leite, C.; Nunes, C.; Jamal, S.K.; Cuccovia, I.M.; Reis, S. Nonsteroidal Anti-Inflammatory Therapy: A Journey Toward Safety. Med. Res. Rev. 2016, 37, 802-859. [CrossRef] [PubMed] 
24. Sandoval, A.C.; Fernandes, D.R.; Silva, E.A.; Terra Júnior, A.T. The indiscriminated use of non-steroid anti-inflammatory (NSAID). Rev. Cient. FAEMA 2017, 8, 165-176. [CrossRef]

25. Sostres, C.; Lanas, Á. Appropriate prescription, adherence and safety of non-steroidal anti-inflammatory drugs. Med. Clin. 2016, 146, 267-272. [CrossRef]

26. Patel, D.P.; Schenk, J.M.; Darke, A.K.; Myers, J.B.; Brant, W.O.; Hotaling, J.M. Non-steroidal anti-inflammatory drug (NSAID) use is not associated with erectile dysfunction risk: Results from the Prostate Cancer Prevention Trial. BJU Int. 2015, 117, 500-506. [CrossRef]

27. Inotai, A.; Hanko, B.; Meszaro, A. Trends in the non-steroidal anti-inflammatory drug market in six central-eastern european countries based on retail information. Pharmacoepidemiol. Drug Saf. 2010, 19, 183-190. [CrossRef]

28. Golden, J.M.; Escobar, O.H.; Nguyen, M.V.L.; Mallicote, M.U.; Kavarian, P.; Frey, M.R.; Gayer, C.P. Ursodeoxycholic acid protects against intestinal barrier breakdown by promoting enterocyte migration via EGFR- and COX-2-dependent mechanisms. Am. J. Physiol. Liver Physiol. 2018, 315, G259-G271. [CrossRef]

29. Suleyman, H.; Demircan, B.; Karagöz, Y. Anti-inflammatory and side effects of cyclooxygenase inhibitors. Pharmacol. Rep. 2007, 59, 247-258.

30. Oliveira, M.M.C.; Silva, M.M.; Moreira, T.L.M.; Couto, V.F.; Coelho, Y.N.; Nunes, C.P. The Chronic Use of Non-Steroid Anti-Inflammatory and Their Adverse Effects. Rev. Cad. Med. 2019, 2, 90-100.

31. Ayyadevara, S.; Bharill, P.; Dandapat, A.; Hu, C.; Khaidakov, M.; Mitra, S.; Reis, R.J.S.; Mehta, J.L. Aspirin Inhibits Oxidant Stress, Reduces Age-Associated Functional Declines, and Extends Lifespan of Caenorhabditis elegans. Antioxid. Redox Signal 2013, 18, 481-490. [CrossRef] [PubMed]

32. Moon, H.-G.; Kim, Y.-S.; Choi, J.-P.; Choi, D.-S.; Yoon, C.M.; Jeon, S.G.; Gho, Y.S.; Kim, Y.-K. Aspirin attenuates the anti-inflammatory effects of theophylline via inhibition of cAMP production in mice with non-eosinophilic asthma. Exp. Mol. Med. 2009, 42, 47-60. [CrossRef] [PubMed]

33. Desborough, M.J.R.; Keeling, D.M. The aspirin story-from willow to wonder drug. Br. J. Haematol. 2017, 177, 674-683. [CrossRef]

34. Bibbins-Domingo, K. Aspirin Use for the Primary Prevention of Cardiovascular Disease and Colorectal Cancer: U.S. Preventive Services Task Force Recommendation Statement. Ann. Intern. Med. 2016, 164, 836. [CrossRef]

35. Hayashi, S.; Sumi, Y.; Ueno, N.; Murase, A.; Takada, J. Discovery of a novel COX-2 inhibitor as an orally potent anti-pyretic and anti-inflammatory drug: Design, synthesis, and structure-activity relationship. Biochem. Pharmacol. 2011, 82, 755-768. [CrossRef] [PubMed]

36. Yaghoobi, R.; Kazerouni, A.; Kazerouni, O. Evidence for Clinical Use of Honey in Wound Healing as an Anti-bacterial, Anti-inflammatory Anti-oxidant and Anti-viral Agent: A Review. Jundishapur J. Nat. Pharm. Prod. 2013, 8, 100-104. [CrossRef]

37. Lucas, G.N.C.; Leitão, A.C.C.; Alencar, R.L.; Xavier, R.M.F.; Daher, E.D.F.; Júnior, G.B.D.S.; Da Silva, G.B. Pathophysiological aspects of nephropathy caused by non-steroidal anti-inflammatory drugs. Braz. J. Nephrol. 2019, 41, 124-130. [CrossRef]

38. Harirforoosh, S.; Asghar, W.; Jamali, F. Adverse effects of nonsteroidal antiinflammatory drugs: An update of gastrointestinal, cardiovascular and renal complications. J. Pharm. Pharm. Sci. 2013, 16, 821-847. [CrossRef]

39. Barakat, A.; Islam, M.S.; Ghawas, H.M.; Al-Majid, A.M.; El-Senduny, F.F.; Badria, F.A.; Elshaier, Y.A.; Ghabbour, H.A. Design and synthesis of new substituted spirooxindoles as potential inhibitors of the MDM2-p53 interaction. Bioorg. Chem. 2019, 86, 598-608. [CrossRef]

40. Abdellatif, K.R.A.; Fadaly, W.A.; Elshaier, Y.A.M.M.; Ali, W.A.; Kamel, G.M. Non-acidic 1,3,4trisubstituted-pyrazole derivatives as lonazolac analogs with promising COX-2 selectivity, anti-inflammatory activity and gastric safety profile. Bioorg. Chem. 2018, 77, 568-578. [CrossRef]

41. El-miligy, M.M.; Hazzaa, A.A.; El-messmary, H.; Nassra, R.A.; E-hawash, S.A. New hybrid molecules combining benzothiophene or benzofuran with rhodanine as dual COX-1/2 and 5-LOX inhibitors: Synthesis, biological evaluation and docking study. Bioorg. Chem. 2017, 72, 102-115. [CrossRef] [PubMed]

42. Barakat, A.; Islam, M.S.; Ghawas, H.M.; Al-Majid, A.M.; El-Senduny, F.F.; Badria, F.A.; Elshaier, Y.A.M.M.; Ghabbour, H.A. Substituted spirooxindole derivatives as potent anticancer agents through inhibition of phosphodiesterase 1. RSC Adv. 2018, 8, 14335-14346. [CrossRef]

43. Owona, B.A.; Abia, W.A.; Moundipa, P.F. Natural compounds flavonoids as modulators of inflammasomes in chronic diseases. Int. Immunopharmacol. 2020, 84, 1-9. [CrossRef] [PubMed] 
44. Anand, P.K. Lipids, inflammasomes, metabolism, and disease. Immunol. Rev. 2020, 1-15. [CrossRef]

45. Newman, D.J. Developing natural product drugs: Supply problems and how they have been overcome. Pharmacol. Therapeut. 2015, 162, 1-9. [CrossRef]

46. Newman, D.J.; Cragg, G.M. Natural Products as Sources of New Drugs from 1981 to 2014. J. Nat. Prod. 2016, 79, 629-661. [CrossRef] [PubMed]

47. Arya, V.; Arya, M.L. A review on anti-inflammatory plant barks. Int. J. Pharm. Tech. Res. 2011, 3, 899-908.

48. Shah, B.; Seth, A.; Maheshwari, K. A Review on Medicinal Plants as a Source of Anti-inflammatory Agents. Res. J. Med. Plant. 2011, 5, 101-115. [CrossRef]

49. Oguntibeju, O.O. Hypoglycaemic and anti-diabetic activity of selected African medicinal plants. Int J. Physiol. Pathophysiol. Pharmacol. 2019, 11, 224-237.

50. Azab, A.N.; Nassar, A.; Azab, A.N. Anti-Inflammatory Activity of Natural Products. Molecules 2016, 21, 1321. [CrossRef]

51. Sharopov, F.; Braun, M.S.; Gulmurodov, I.; Khalifaev, D.; Isupov, S.; Wink, M. Antimicrobial, antioxidant, and anti-inflammatory activities of essential oils of selected aromatic plants from Tajikistan. Foods 2015, 4, 645-653. [CrossRef] [PubMed]

52. Bauri, R.K.; Tigga, M.N.; Saleebkullu, S. A review on use of medicinal plants to control parasites. J. Nat. Prod. Resour. 2015, 6, 268-277.

53. Cabral, B.; Siqueira, E.M.S.; Bitencourt, M.A.O.; Lima, M.C.J.S.; Lima, A.K.; Ortmannd, C.F.; Chaves, V.C.; Fernandes-Pedrosa, M.F.; Rochac, H.A.O.; Scortecci, K.C.; et al. Phytochemical study and anti-inflammatory and antioxidant potential of Spondias mombin leaves. Rev. Bras. Farmacog. 2016, 26, 304-311. [CrossRef]

54. Barbosa, H.M.; Nascimento, J.N.D.; Araújo, T.A.; Duarte, F.S.; Albuquerque, U.P.; Vieira, J.R.; De Santana, E.R.; Yara, R.; Lima, C.S.; Lira, E.C.; et al. Acute Toxicity and Cytotoxicity Effect of Ethanolic Extract of Spondias tuberosa Arruda Bark: Hematological, Biochemical and Histopathological Evaluation. An. Acad. Bras. Ciênc. 2016, 88, 1993-2004. [CrossRef] [PubMed]

55. Rosas, E.; Correa, L.B.; Pádua, T.D.A.; Costa, T.E.M.M.; Mazzei, J.L.; Heringer, A.P.; Bizarro, C.A.; Kaplan, M.A.C.; Figueiredo, M.R.; Henriques, M.D.G.M.O. Anti-inflammatory effect of Schinus terebinthifolius Raddi hydroalcoholic extract on neutrophil migration in zymosan-induced arthritis. J. Ethnopharmacol. 2015, 175, 490-498. [CrossRef]

56. Mostofora, R.; Ahmed, S.; Begum, M.M.; Rahman, M.S.; Begum, T.; Ahmed, S.U.; Tuhin, R.H.; Das, M.; Hossain, A.; Sharma, M.; et al. Evaluation of anti-inflammatory and gastric anti-ulcer activity of Phyllanthus niruri L. (Euphorbiaceae) leaves in experimental rats. BMC Complement Altern. Med. 2017, $17,267$.

57. Zahidin, N.S.; Saidin, S.; Zulkifli, R.M.; Muhamad, I.I.; Ya'Akob, H.; Nur, H. A review of Acalypha indica L. (Euphorbiaceae) as traditional medicinal plant and its therapeutic potential. J. Ethnopharmacol. 2017, 207, 146-173. [CrossRef]

58. Siraj, A.; Shilpi, J.A.; Hossain, G.; Uddin, S.J.; Islam, K.; Jahan, I.A.; Hossain, H. Anti-Inflammatory and Antioxidant Activity of Acalyphahispida Leaf and Analysis of its Major Bioactive Polyphenols by HPLC. Adv. Pharm. Bull. 2016, 6, 275-283. [CrossRef]

59. Rios, R.; Silva, H.B.F.; Carneiro, N.V.Q.; Costa, R.S.; Carneiro, T.C.B.; Marques, C.R.; Machado, M.S.S.; Velozo, E.S.; Silva, T.M.; Silva, T.M.S.; et al. Anti-inflammatory Activity of Jurubeba (Solanum paniculatum L.) Through Reducing the T-bet and GATA3 Gene Expression, In Vitro. J. Allergy Clin. Immunol. 2017, 139, AB268. [CrossRef]

60. Ortiz, M.I.; Fernández-Martínez, E.; Soria-Jasso, L.E.; Lucas-Gómez, I.; Villagómez-Ibarra, R.; González-García, M.P.; Castañeda-Hernández, G.; Salinas-Caballero, M. Isolation, identification and molecular docking as cyclooxygenase (COX) inhibitors of the main constituents of Matricaria chamomilla $\mathrm{L}$. extract and its synergistic interaction with diclofenac on nociception and gastric damage in rats. Biomed. Pharmacother. 2016, 78, 248-256. [CrossRef]

61. Kyei, S.; Koffuor, G.; Ramkissoon, P.; Ameyaw, E.O.; Asiamah, E.A. Anti-inflammatory effect of Heliotropium indicum Linn on lipopolysaccharide-induced uveitis in New Zealand white rabbits. Int. J. Ophthalmol. 2016, 9, 528-535. [CrossRef]

62. Cruz, M.P.; Andrade, C.M.F.; Silva, K.O.; De Souza, E.P.; Yatsuda, R.; Marques, L.M.; David, J.P.; David, J.M.; Napimoga, M.H.; Clemente-Napimoga, J.T. Antinoceptive and Anti-inflammatory Activities of the Ethanolic Extract, Fractions and Flavones Isolated from Mimosa tenuiflora (Willd.) Poir (Leguminosae). PLoS ONE 2016, 11, e0150839. [CrossRef] [PubMed] 
63. Funk, J.L.; Frye, J.B.; Oyarzo, J.N.; Chen, J.; Zhang, H.; Timmermann, B.N. Anti-Inflammatory Effects of the Essential Oils of Ginger (Zingiber officinale Roscoe) in Experimental Rheumatoid Arthritis. PharmaNutrition 2016, 4, 123-131. [CrossRef]

64. Maione, F.; Russo, R.; Khan, H.; Mascolo, N. Medicinal plants with anti-inflammatory activities. Nat. Prod. Res. 2015, 30, 1343-1352. [CrossRef] [PubMed]

65. Rtibi, K.; Selmi, S.; Jabri, M.-A.; Mamadou, G.; Limas-Nzouzi, N.; Sebai, H.; El-Benna, J.; Marzouki, L.; Eto, B.; Amri, M. Effects of aqueous extracts from Ceratonia siliqua L. pods on small intestinal motility in rats and jejunal permeability in mice. RSC Adv. 2016, 6, 44345-44353. [CrossRef]

66. Atanasov, A.G.; Waltenberger, B.; Pferschy-Wenzig, E.-M.; Linder, T.; Wawrosch, C.; Uhrin, P.; Temml, V.; Wang, L.; Schwaiger, S.; Heiss, E.H.; et al. Discovery and resupply of pharmacologically active plant-derived natural products: A review. Biotechnol. Adv. 2015, 33, 1582-1614. [CrossRef]

67. Walker, J.; Reichelt, K.V.; Obst, K.; Widder, S.; Hans, J.; Krammer, G.E.; Ley, J.; Somoza, V. Identification of an anti-inflammatory potential of Eriodictyon angustifolium compounds in human gingival fibroblasts. Food Funct. 2016, 7, 3046-3055. [CrossRef]

68. Asadi-Samani, M.; Kafash-Farkhad, N.; Azimi, N.; Fasihi, A.; Alinia-Ahandani, E.; Rafieian-Kopaei, M. Medicinal plants with hepatoprotective activity in Iranian folk medicine. Asian Pac. J. Trop. Biomed. 2015, 5, 146-157. [CrossRef]

69. Dewick, P.M. Medicinal Natural Products; Wiley: Chichester, UK, 2009; p. 550.

70. Płonka, J.; Górny, A.; Kokoszka, K.; Barchanska, H. Metabolic profiles in the course of the shikimic acid pathway of Raphanus sativus var. longipinnatus exposed to mesotrione and its degradation products. Chemosphere 2020, 245, 125616. [CrossRef] [PubMed]

71. Wellen, K.E.; Thompson, C.B. A two-way street: Reciprocal regulation of metabolism and signalling. Nat. Rev. Mol. Cell Boil. 2012, 13, 270-276. [CrossRef] [PubMed]

72. Santos-Sánchez, N.F.; Salas-Coronado, R.; Hernández-Carlos, B.; Villanueva-Cañongo, C. Shikimic Acid Pathway in Biosynthesis of Phenolic Compounds. In Plant Physiological Aspects of Phenolic Compounds; IntechOpen: London, UK, 2019. [CrossRef]

73. Heinrich, M. Fundamentals of Pharmacognosy and Phytotherapy, 2nd ed.; Churchill Livingstone/Elsevier: Edinburgh, UK, 2012; p. 326.

74. Kite, G.; Dewick, P.M. Medicinal Natural Products: A Biosynthetic Approach. Kew Bull. 1998, 53, 499. [CrossRef]

75. Bose, S.; Ramesh, V.; Locasale, J.W. Acetate Metabolism in Physiology, Cancer, and Beyond. Trends Cell Boil. 2019, 29, 695-703. [CrossRef]

76. Karam, T.K.; Dalposso, L.M.; Casa, D.M.; De Freitas, G.B.L. Broom (Baccharis trimera): Therapeutic use and biosynthesis. Rev. Bras. Plantas Med. 2013, 15, 280-286. [CrossRef]

77. Jesch, E.D.; Carr, T.P. Food Ingredients That Inhibit Cholesterol Absorption. Prev. Nutr. Food Sci. 2017, 22, 67-80.

78. Le Pogam, P.; Boustie, J. Xanthones of Lichen Source: A 2016 Update. Molecules 2016, 21, 294. [CrossRef] [PubMed]

79. Li, J.J.; Corey, E.J. Total Synthesis of Natural Products; Springer Science \& Business Media: Berlin/Heidelberg, Germany, 2013; p. 295. [CrossRef]

80. Serafini, M.; Peluso, I.; Raguzzini, A. Flavonoids as anti-inflammatory agents. Proc. Nutr. Soc. 2010, 69, 273-278. [CrossRef] [PubMed]

81. Bi, W.; Bi, Y.; Gao, X.; Yan, X.; Zhang, Y.; Xue, P.; Bammert, C.E.; LeGalley, T.D.; Gibson, K.M.; Bi, L.; et al. Anti-inflammatory, analgesic and antioxidant activities of novel kyotorphin-nitroxide hybrid molecules. Bioorganic Med. Chem. Lett. 2016, 26, 2005-2013. [CrossRef] [PubMed]

82. Mondal, A.; Gandhi, A.; Fimognari, C.; Atanasov, A.G.; Bishayee, A. Alkaloids for cancer prevention and therapy: Current progress and future perspectives. Eur. J. Pharmacol. 2019, 858, 172472. [CrossRef] [PubMed]

83. Hussein, R.A.; El-Anssary, A.A. Plants Secondary Metabolites: The Key Drivers of the Pharmacological Actions of Medicinal Plants. Herb. Med. 2019, 2, 11-30. [CrossRef]

84. Singh, B.; Sharma, R.A. Plant terpenes: Defense responses, phylogenetic analysis, regulation and clinical applications. 3 Biotech 2014, 5, 129-151. [CrossRef] 
85. Gorlenko, C.L.; Kiselev, H.Y.; Budanova, E.V.; Zamyatnin, J.A.A.; Ikryannikova, L.N. Plant Secondary Metabolites in the Battle of Drugs and Drug-Resistant Bacteria: New Heroes or Worse Clones of Antibiotics? Antibiotics 2020, 9, 170. [CrossRef] [PubMed]

86. Muthukrishnan, S.D.; Subramaniyan, A. Phytochemical Constituents of Gloriosa superba Seed, Tuber and Leaves. Res. J. Pharm. Biol. Chem. Sci. 2012, 3, 111-117.

87. Mitra, I.; Saha, A.; Roy, K. Exploring quantitative structure-activity relationship studies of antioxidant phenolic compounds obtained from traditional Chinese medicinal plants. Mol. Simul. 2010, 36, 1067-1079. [CrossRef]

88. Rex, J.R.S.; Muthukumar, N.M.S.A.; Selvakumar, P.M. Phytochemicals as a potential source for anti-microbial, anti-oxidant and wound healing-A review. MOJ Bioorg. Org. Chem. 2018, 2, 1. [CrossRef]

89. Rajkapoor, B.; Burkan, Z.E.; Senthilkumar, R. Oxidants and human diseases: Role of antioxidant medicinal plants-A review. Pharmacologyonline 2010, 1, 1117-1131.

90. Saxena, M.; Saxena, J.; Nema, R.; Singh, D.; Gupta, A. Phytochemistry of Medicinal Plants. J. Pharmacogn. Phytochem. 2013, 1, 168-182.

91. Torres, D.A.; Pereira, E.C.V.; Sampaio, P.A.; Souza, N.A.C.; Ferraz, C.A.A.; Oliveira, A.P.; Moura, C.A.; Almeida, J.R.G.S.; Rolim-Neto, P.K.; Oliveira-Júniora, R.G.; et al. Influence of extraction process on flavonoid content from Cnidoscolus quercifoliuspohl (euhorbiaceae) and antioxidant activity. Quim. Nova 2018, 41, 743-747.

92. Saxena, M.; Saxena, J.; Pradhan, A. Flavonoids and phenolic acids as antioxidants in plants and human health. Int. J. Pharm. Sci. Rev. Res. 2012, 16, 130-134.

93. Ara, T.; Nakatani, S.; Kobata, K.; Sogawa, N.; Sogawa, C. The Biological Efficacy of Natural Products against Acute and Chronic Inflammatory Diseases in the Oral Region. Medicines 2018, 5, 122. [CrossRef]

94. Reginato, F.Z.; Da Silva, A.R.H.; Bauermann, L.F. Evaluation of the flavonoides use in the treatment of the inflammation. Rev. Cuba. Farm. 2015, 49, 569-582.

95. Aravindaram, K.; Yang, N.-S. Anti-Inflammatory Plant Natural Products for Cancer Therapy. Planta Med. 2010, 76, 1103-1117. [CrossRef]

96. Lucas, L.; Russell, A.; Keast, R. Molecular mechanisms of inflammation. Anti-inflammatory benefits of virgin olive oil and the phenolic compound oleocanthal. Curr. Pharm. Des. 2011, 17, 754-768. [CrossRef]

97. Teixeira, T.O.; Campos, K.M.; Cerqueira-Lima, A.T.; Carneiro, T.C.B.; Velozo, E.D.S.; De Melo, I.C.; Figueiredo, E.A.; Oliveira, E.; Silva, D.F.; Ivan, R.C.; et al. Potential therapeutic effect of Allium cepa L. and quercetin in a murine model of Blomia tropicalis induced asthma. DARU J. Pharm. Sci. 2015, 23, 18. [CrossRef]

98. Kaladhar, D.S.V.G.K.; Swathi, S.K.; Varahalarao, V.; Nagendra, S.Y. Evaluation of Anti-inflammatory and Anti-proliferative Activity of Abutilon indicum L. Plant Ethanolic Leaf Extract on Lung Cancer Cell Line A549 for System Network Studies. J. Cancer Sci. Ther. 2014, 6, 188-194. [CrossRef]

99. Bose, S.; Laha, B.; Banerjee, S. Anti-inflammatory activity of isolated allicin from garlic with post-acoustic waves and microwave radiation. J. Adv. Pharm. Educ. Res. 2013, 3, 512-515.

100. Szeja, W.; Grynkiewicz, G.; Rusin, A. Isoflavones, their Glycosides and Glycoconjugates. Synthesis and Biological Activity. Curr. Org. Chem. 2017, 21, 218-235. [CrossRef]

101. Díaz-Tielas, C.; Reigosa, M.; Sánchez-Moreiras, A.; Graña, E. Biological activities and novel applications of chalcones. Planta Daninha 2016, 34, 607-616. [CrossRef]

102. Roy, A. A review on the alkaloids an important therapeutic compound from plants. Int. J. Plant Biol. 2017, 3, 1-9.

103. Carlos, L.D.A.; Amaral, K.A.D.S.; Vieira, I.J.C.; Mathias, L.; Braz-Filho, R.; Samarão, S.S.; Da Motta, O.V. Rauvolfia Grandiflora (Apocynaceae) Extract Interferes with Staphylococcal Density, Enterotoxin Production and Antimicrobial Activity. Braz. J. Microbiol. 2010, 41, 612-620. [CrossRef]

104. Dey, P.; Kundu, A.; Kumar, A.; Gupta, M.; Lee, B.M.; Bhakta, T.; Dash, S.; Kim, H.S. Analysis of alkaloids (indole alkaloids, isoquinoline alkaloids, tropane alkaloids). In Recent Advances in Natural Products Analysis; Elsevier: Amsterdam, The Netherlands, 2020; pp. 505-567. [CrossRef]

105. Sandini, T.M.; Udo, M.S.B.; Spinosa, H.D.S. Senecio brasiliensis e alcaloides pirrolizidínicos: Toxicidade em animais e na saúde humana. Biotemas 2013, 26, 83-92. [CrossRef]

106. Smeriglio, A.; Barreca, D.; Bellocco, E.S.; Trombetta, D. Proanthocyanidins and hydrolysable tannins: Occurrence, dietary intake and pharmacological effects. Br. J. Pharmacol. 2016, 174, 1244-1262. [CrossRef] 
107. Xie, L.; Roto, A.V.; Bolling, B.W. Characterization of Ellagitannins, Gallotannins, and Bound Proanthocyanidins from California Almond (Prunus dulcis) Varieties. J. Agric. Food Chem. 2012, 60, 12151-12156. [CrossRef]

108. He, M.; Tian, H.; Luo, X.; Qi, X.-H.; Chen, X. Molecular Progress in Research on Fruit Astringency. Molecules 2015, 20, 1434-1451. [CrossRef] [PubMed]

109. Jain, P.; Joshi, H. Coumarin: Chemical and pharmacological profile. J. Appl. Pharm. Sci. 2012, 2, $236-240$.

110. Gupta, A.; Chaphalkar, S.R. Terpenoids from three medicinal plants and their potential anti-inflammatory and immunosuppressive activity on human whole blood and peripheral blood mononuclear cells. Asian J. Ethnopharmacol. Med. Foods 2016, 2, 13-17.

111. Gu, J.; Luo, L.; Wang, Q.; Yan, S.; Lin, J.; Li, D.; Cao, B.; Mei, H.; Ying, B.; Bin, L.; et al. Maresin 1 attenuates mitochondrial dysfunction through the ALX/cAMP/ROS pathway in the cecal ligation and puncture mouse model and sepsis patients. Lab. Investig. 2018, 98, 715-733. [CrossRef] [PubMed]

112. Alkhalaf, M.I.; Alansari, W.S.; Ibrahim, E.A.; Elhalwagy, M.E. Anti-oxidant, anti-inflammatory and anti-cancer activities of avocado (Persea americana) fruit and seed extract. J. King Saud Univ. Sci. 2019, 31, 1358-1362. [CrossRef]

113. Mensah, J.K.; Golomeke, D. Antioxidant and antimicrobial activities of the extracts of the Calyx of Hibiscus Sabdariffa Linn. Curr. Sci. Perspectiv. 2015, 1, 69-76.

114. Zhang, Y.F.; Sun, C.C.; Duan, J.X.; Yang, H.H.; Zhang, C.Y.; Xiong, J.B.; Zhong, W.J.; Zu, C.; Guan, X.X.; Jiang, H.L.; et al. A COX-2/sEH dual inhibitor PTUPB ameliorates cecal ligation and punctureinduced sepsis in mice via anti-inflammation and anti-oxidative stress. Biomed. Pharmacother. 2020, 126, 109907. [CrossRef]

115. Sun, L.-C.; Zhang, H.-B.; Gu, C.-D.; Guo, S.-D.; Li, G.; Lian, R.; Yao, Y.; Zhang, G.-Q. Protective effect of acacetin on sepsis-induced acute lung injury via its anti-inflammatory and antioxidative activity. Arch. Pharmacal. Res. 2017, 41, 1199-1210. [CrossRef]

116. Hattori, Y.; Hattori, K.; Suzuki, T.; Matsuda, N. Recent advances in the pathophysiology and molecular basis of sepsis-associated organ dysfunction: Novel therapeutic implications and challenges. Pharmacol. Ther. 2017, 177, 56-66. [CrossRef]

117. Wenzel, P.; Kossmann, S.; Münzel, T.; Daiber, A. Redox regulation of cardiovascular inflammation-Immunomodulatory function of mitochondrial and Nox-derived reactive oxygen and nitrogen species. Free Radic. Boil. Med. 2017, 109, 48-60. [CrossRef]

118. Bernardes, N.R.; Pessanha, F.F.; Oliveira, D.B. Alimentos Funcionais: Uma breve revisão. Ciênc. Cult. 2010, 6, 2. (In Portuguese)

119. Chen, X.; Wang, Y.; Xie, X.; Chen, H.; Zhu, Q.; Ge, Z.; Wei, H.; Deng, J.; Zhongyuan, X.; Lian, Q. Heme Oxygenase-1 Reduces Sepsis-Induced Endoplasmic Reticulum Stress and Acute Lung Injury. Mediat. Inflamm. 2018, 2018, 1-10. [CrossRef]

120. Adebayo, S.A.; Ondua, M.; Shai, L.; Lebelo, S.L. Inhibition of nitric oxide production and free radical scavenging activities of four South African medicinal plants. J. Inflamm. Res. 2019, 12, 195-203. [CrossRef]

121. Altowyan, M.S.; Barakat, A.; Al-Majid, A.M.; Al-Ghulikah, H. Spiroindolone analogues bearing benzofuran moiety as a selective cyclooxygenase COX-1 with TNF- $\alpha$ and IL-6 inhibitors. Saudi J. Boil. Sci. 2020, 27, 1208-1216. [CrossRef]

122. Wilson, J.C.; Anderson, L.A.; Murray, L.J.; Hughes, C.M. Non-steroidal anti-inflammatory drug and aspirin use and the risk of head and neck cancer: A systematic review. Cancer Causes Control 2011, 22, 803-810. [CrossRef]

123. Halliwell, B. The wanderings of a free radical. Free Radic. Boil. Med. 2009, 46, 531-542. [CrossRef]

124. Ali, S.S.; Kasoju, N.; Luthra, A.; Singh, A.; Sharanabasava, H.; Sahu, A.; Bora, U. Indian medicinal herbs as sources of antioxidants. Food Res. Int. 2008, 41, 1-15. [CrossRef]

125. González-Costa, M.; Padrón González, A.A. Inflammation from an immunologic perspective: A challenge to medicine in the 21st century. Rev. Haban. Cienc. Méd. 2018, 18, 30-44.

126. Artis, D.; Spits, H. The biology of innate lymphoid cells. Nature 2015, 517, 293-301. [CrossRef]

127. Padrón-González, A.; Dorta-Contreras. Vía de las lectinas, una ruta del complemento en construcción. Arch. Alerg. Inmunol. Clin. 2018, 49, 0005-0012. (In Spanish)

128. Isailovic, N.; Daigo, K.; Mantovani, A.; Selmi, C. Interleukin-17 and innate immunity in infections and chronic inflammation. J. Autoimmun. 2015, 60, 1-11. [CrossRef] 
129. Chousterman, B.G.; Świrski, F.K.; Weber, G.F. Cytokine storm and sepsis disease pathogenesis. Semin. Immunopathol. 2017, 39, 517-528. [CrossRef]

130. Parhiz, H.; Roohbakhsh, A.; Soltani, F.; Rezaee, R.; Iranshahi, M. Antioxidant and Anti-Inflammatory Properties of the Citrus Flavonoids Hesperidin and Hesperetin: An Updated Review of their Molecular Mechanisms and Experimental Models. Phytother. Res. 2014, 29, 323-331. [CrossRef]

131. Bassiouni, W.; Daabees, T.; Louedec, L.; Norel, X.; Senbel, A.M. Evaluation of some prostaglandins modulators on rat corpus cavernosum in-vitro: Is relaxation negatively affected by COX-inhibitors? Biomed. Pharmacother. 2019, 111, 1458-1466. [CrossRef]

132. Zeliha, P.K.; Dilek, O.; Ezgi, O.; Halil, K.; Cihan, U.; Gul, O. Association between ABCB1, ABCG2 carrier protein and COX-2 enzyme gene polymorphisms and breast cancer risk in a Turkish population. Saudi Pharm. J. 2020, 28, 215-219. [CrossRef]

133. Ucan, B.; Özbek, M.; Sahin, M.; Kızılgül, M.; Çakal, E. Cyclooxygenase-2 (COX-2) gene polymorphism in patients with differentiated thyroid carcinomas in the Turkish population. Turk. J. Med. Sci. 2017, 47, 1848-1853. [CrossRef]

134. Lelubre, C.; Vincent, J.-L. Mechanisms and treatment of organ failure in sepsis. Nat. Rev. Nephrol. 2018, 14, 417-427. [CrossRef]

135. Gotts, J.E.; Matthay, M.A. Sepsis: Pathophysiology and clinical management. Br. Med. J. 2016, $353, \mathrm{i} 1585$. [CrossRef]

136. Van Der Poll, T.; Van De Veerdonk, F.L.; Scicluna, B.P.; Netea, M.G. The immunopathology of sepsis and potential therapeutic targets. Nat. Rev. Immunol. 2017, 17, 407-420. [CrossRef]

137. Davis, C.M.; Liu, X.; Alkayed, N.J. Cytochrome P450 eicosanoids in cerebrovascular function and disease. Pharmacol. Ther. 2017, 179, 31-46. [CrossRef]

138. Hanke, T.; Merk, D.; Steinhilber, D.; Geisslinger, G.; Schubert-Zsilavecz, M. Small molecules with anti-inflammatory properties in clinical development. Pharmacol. Ther. 2016, 157, 163-187. [CrossRef]

139. Wu, J.; Liu, B.; Mao, W.; Feng, S.; Yao, Y.; Bai, F.; Shen, Y.; Guleng, A.; Jirigala, B.; Cao, J. Prostaglandin E2 Regulates Activation of Mouse Peritoneal Macrophages by Staphylococcus aureus through Toll-Like Receptor 2, Toll-Like Receptor 4, and NLRP3 Inflammasome Signaling. J. Innate Immun. 2019, 12, 154-169. [CrossRef]

140. Gartung, A.; Yang, J.; Sukhatme, V.P.; Bielenberg, D.R.; Fernandes, D.; Chang, J.; Schmidt, B.A.; Hwang, S.H.; Zurakowski, D.; Huang, S.; et al. Suppression of chemotherapy-induced cytokine/lipid mediator surge and ovarian cancer by a dual COX-2/sEH inhibitor. Proc. Natl. Acad. Sci. USA 2019, 116, 1698-1703. [CrossRef]

141. Darwesh, A.M.; Jamieson, K.L.; Wang, C.; Samokhvalov, V.; Seubert, J.M. Cardioprotective effects of CYP-derived epoxy metabolites of docosahexaenoic acid involve limiting NLRP3 inflammasome activation. Can. J. Physiol. Pharmacol. 2019, 97, 544-556. [CrossRef]

142. Yang, L.; Zhang, H.; Chen, P. Sulfur dioxide attenuates sepsis-induced cardiac dysfunction via inhibition of NLRP3 inflammasome activation in rats. Nitric Oxide 2018, 81, 11-20. [CrossRef]

143. Schunck, W.-H.; Konkel, A.; Fischer, R.; Weylandt, K.-H. Therapeutic potential of omega-3 fatty acid-derived epoxyeicosanoids in cardiovascular and inflammatory diseases. Pharmacol. Ther. 2018, 183, 177-204. [CrossRef]

144. Rahim, I.; Djerdjouri, B.; Sayed, R.K.A.; Ortiz, F.; Fernandez-Gil, B.I.; Hidalgo-Gutiérrez, A.; Lopez, L.C.; Escames, G.; Reiter, R.J.; Acuña-Castroviejo, D. Melatonin administration to wild-type mice and nontreated NLRP3 mutant mice share similar inhibition of the inflammatory response during sepsis. J. Pineal Res. 2017, 63, e12410. [CrossRef]

145. Zhang, W.; Tao, A.; Lan, T.; Cepinskas, G.; Kao, R.; Martin, C.M.; Rui, T. Carbon monoxide releasing molecule-3 improves myocardial function in mice with sepsis by inhibiting NLRP3 inflammasome activation in cardiac fibroblasts. Basic Res. Cardiol. 2017, 112, 16. [CrossRef]

146. Dong, L.; Zhou, Y.; Zhu, Z.-Q.; Liu, T.; Duan, J.-X.; Zhang, J.; Li, P.; Hammcok, B.D.; Guan, C.-X. Soluble Epoxide Hydrolase Inhibitor Suppresses the Expression of Triggering Receptor Expressed on Myeloid Cells-1 by Inhibiting NF-kB Activation in Murine Macrophage. Inflammation 2016, 40, 13-20. [CrossRef]

147. Hye Khan, M.A.; Hwang, S.H.; Sharma, A.; Corbett, J.A.; Hammock, B.D.; Imig, J.D. A dual COX-2/sEH inhibitor improves the metabolic profile and reduces kidney injury in Zucker diabetic fatty rat. Prostag. Oth. Lipid Mediat. 2016, 125, 40-47. [CrossRef] 
148. Warner, T.D.; Mitchell, J.A. Cyclooxygenase-3 (COX-3): Filling in the gaps toward a COX continuum? Proc. Natl. Acad. Sci. USA 2002, 99, 13371-13373. [CrossRef]

149. Ge, Y.; Huang, M.; Yao, Y.-M. Recent advances in the biology of IL-1 family cytokines and their potential roles in development of sepsis. Cytokine Growth Factor Rev. 2019, 45, 24-34. [CrossRef]

150. Mckenna, S.; Eckman, M.; Parker, A.; Bok, R.; Hurt, K.J.; Wright, C.J. Perinatal endotoxemia induces sustained hepatic COX-2 expression through an NFkappaB-Dependent mechanism. J. Innate Immun. 2016, 8, 386-399. [CrossRef]

(c)

(C) 2020 by the authors. Licensee MDPI, Basel, Switzerland. This article is an open access article distributed under the terms and conditions of the Creative Commons Attribution (CC BY) license (http://creativecommons.org/licenses/by/4.0/). 